\title{
Ampulse Corporation: A Case Study on Technology Transfer in U.S. Department of Energy Laboratories
}

Technical Report NREL/TP-7A1-46860

March 2010

Thomas D. Perry IV 


\section{Ampulse Corporation: A Case Study on Technology Transfer in U.S. Department of Energy Laboratories}

\section{Thomas D. Perry IV}

Prepared under Task No. 7A10.1000

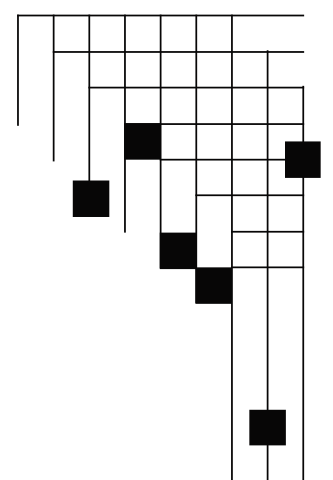




\section{NOTICE}

This report was prepared as an account of work sponsored by an agency of the United States government. Neither the United States government nor any agency thereof, nor any of their employees, makes any warranty, express or implied, or assumes any legal liability or responsibility for the accuracy, completeness, or usefulness of any information, apparatus, product, or process disclosed, or represents that its use would not infringe privately owned rights. Reference herein to any specific commercial product, process, or service by trade name, trademark, manufacturer, or otherwise does not necessarily constitute or imply its endorsement, recommendation, or favoring by the United States government or any agency thereof. The views and opinions of authors expressed herein do not necessarily state or reflect those of the United States government or any agency thereof.

Available electronically at http://www.osti.gov/bridge

Available for a processing fee to U.S. Department of Energy and its contractors, in paper, from:

U.S. Department of Energy

Office of Scientific and Technical Information

P.O. Box 62

Oak Ridge, TN 37831-0062

phone: 865.576 .8401

fax: 865.576 .5728

email: mailto:reports@adonis.osti.gov

Available for sale to the public, in paper, from:

U.S. Department of Commerce

National Technical Information Service

5285 Port Royal Road

Springfield, VA 22161

phone: 800.553.6847

fax: 703.605.6900

email: orders@ntis.fedworld.gov

online ordering: http://www.ntis.gov/ordering.htm 


\section{List of Acronyms}

CRADA

DOE

EERE

IP

NREL

R\&D

RABiTS

ROI

TCDF

$\mathrm{VC}$ cooperative research and development agreement U.S. Department of Energy

Office of Energy Efficiency and Renewable Energy intellectual property

National Renewable Energy Laboratory

research and development

rolling assisted biaxially textured substrates

record of invention

Technology Commercialization and Development

Fund

venture capitalist 


\section{Table of Contents}

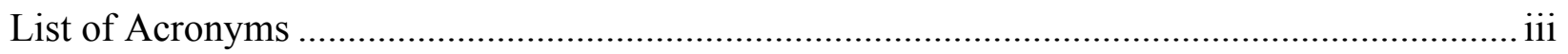

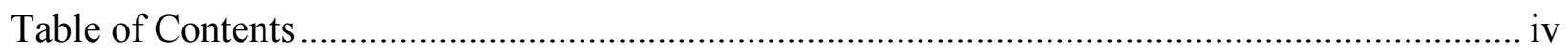

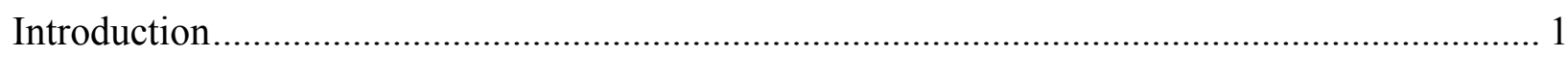

National Laboratories and Technology Transfer ..................................................................... 1

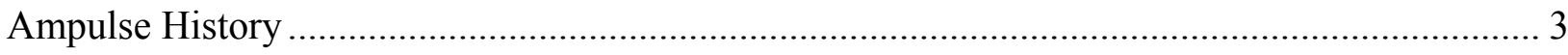

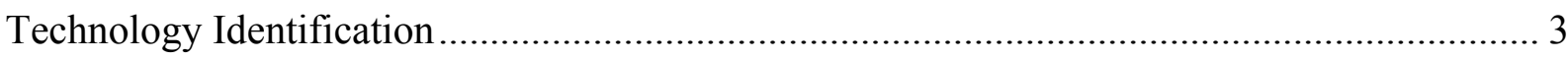

Ampulse Corporation: A Virtual Company-A New Technology Transfer Model ................... 4

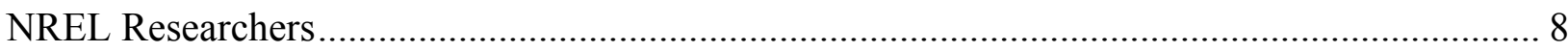

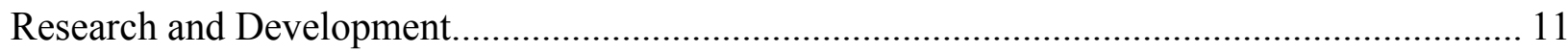

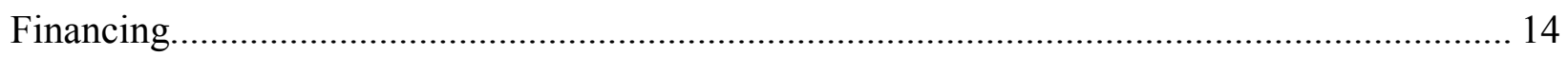

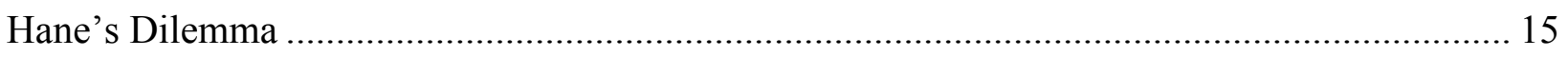

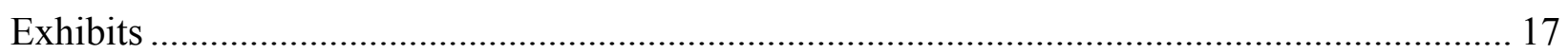


We are going to produce a 15\%+ efficient, 50-cents per watt working solar cell for a grand total investment of $\$ 10$ million; some people spend ten times that! We're going to be able to do that because we are working together with the national labs, cracking the code on how to clean up the interface between pure $R \& D$ and commercialization.

\author{
—Steve Hane, CEO, Ampulse
}

\title{
Introduction
}

It was just after the 2009 New Year and Steve Hane, CEO of Ampulse Corporation, tightened the knot on his tie and walked down into the company's office in the basement of his house west of Denver, Colorado. He found that, even though he wasn't going into the fancy corporate offices he had experienced in his several previous C-level jobs, occasionally putting on a suit to go to his "virtual company" offices helped him keep serious and energized about Ampulse's business prospects. Ampulse performed its research and development with research partners - two U.S. Department of Energy (DOE) national laboratories - and Hane was the only employee. At the same time, Ampulse faced "real company" challenges, such as how to manage a complex research and development (R\&D) project, how to control how much money it was spending, and how to plan for hiring. Hane was at a crossroads: He was about two months away from running out of money and had to determine how to raise more money and get the national labs to finally achieve what they said would be completed six months ago; or maybe there was just too deep a cultural divide between a start-up and the labs, and he should just walk away. As Hane arrived in the basement and powered-up his computer, he knew it was going to be a long day.

\section{National Laboratories and Technology Transfer}

Oak Ridge National Laboratory (Oak Ridge) and the National Renewable Energy Laboratory (NREL) are labs in the DOE national laboratory system (Exhibit 1), which "house world-class facilities where more than 30,000 scientists and engineers perform cutting-edge research." [1] Both Oak Ridge and NREL are government-owned contractor-operated facilities. This arrangement allows a private contractor to operate the federal facility on behalf of the federal government under a prime contract. This relationship can be confusing in terms of the labs defining their missions, however, because the labs are not purely governmental, industrial, or academic, which has certain connotations about the type of research the labs should be doingapplied, commercial, and basic, respectively. [2] Battelle Memorial Institute (Battelle), which is responsible for managing both of these labs with other partners, is a nonprofit charitable trust committed to "[b]uild[ing] long-term relationships with our clients by anticipating their needs and delivering economically and socially valuable science and technology" [3] (Exhibit 2).

The national labs receive research and development funding from Congress, which is used for a variety of research programs in different technology areas (see sample budget in Exhibit 3). In addition to federal funding, the laboratories - especially those that are market focused, such as NREL - have private clients and research partners. Certainly, NREL's primary client is DOE's Office of Energy Efficiency and Renewable Energy (EERE). They also work closely with 
industry, however, and are planning to grow substantially their proprietary work with private partners. These clients can have very different paradigms for evaluating and rewarding technology development and transfer success, [4] and there is concern that too much focus on technology transfer might distract from the lab's "basic research, technology development, and education." [5] Additionally, there appears to be an inherent conflict for the lab in having a diverse client base, because it leads to variation in the relative amounts of influence that the government and market have on the research and development work. [2] Lastly, the operation of a robust private-public cooperative research and development program - as measured by the number of CRADAs (cooperative research and development agreements) - is not an indicator of technology transfer success, which is the presumed reason to work with the private sector. [5] Market-facing operations and commercial ties are important factors for successful commercialization of technologies but not necessarily for technology transfer. [6]

Historically, the laboratories performed research and distributed it into the public sector, usually through publication and other nonproprietary mechanisms. The typical nonproprietary mechanisms of technology transfer [7] are described below.

- Peer-reviewed publications are a means of technology transfer because they disseminate knowledge into society, although they often are viewed as the least-effective mechanism for doing so.

- Informal conversations in which technical information is exchanged can be perceived as a mechanism of technology transfer.

Technology transfer was added to the mission of the laboratories to help enhance the chance of commercial impact and societal benefit justifying the taxpayer investment in the laboratories' research and other activities. [8] The policy foundation for technology transfer was enacted through three important pieces of federal legislation, listed below. $[4,6,9]$

- The Stevenson-Wydler Technology Innovation Act of 1980 (Pub. L. No. 96-480) added technology transfer to federally funded laboratories' missions "to ensure the full use of the results of the nation's federal investment in research and development," and provided the ability to use part of the federal budget for this purpose.

- The Bayh-Dole Act or The University and Small Business Patent Procedures Act of 1980 (Pub. L. No. 96-517) allowed federally funded small businesses and nonprofit institutions to take title (ownership) to the intellectual property created during their work.

- The Federal Technology Transfer Act of 1986 (Pub. L. No. 99-502) allowed federal laboratories to enter into cooperative research and development agreements (CRADAs) with private, for-profit companies. The companies and the laboratories would both provide resources - financial, human, capital - to conduct mutually beneficial research. Any resultant intellectual property could be sequestered for up to five years and licensed exclusively to the company partner without the otherwise mandated public notice (freedom of information) requirement. The laboratory has the ability to negotiate the license with the company according to its own objectives, with clauses stipulating that the government retains a nonexclusive royalty-free license to the technology and that any products of the license must be substantially manufactured in the United States. 
Similar to other nonprofit federally funded research organizations like universities, the labs then were able to protect the intellectual property they created. This intellectual property could be transferred into the commercial sector. See Exhibit 4 for a schematic of the typical technology development and transfer process. Intellectual property licensing is the situation in which the rights to make and sell a protected product are contractually provided to a company in exchange for fees, revenue or sales sharing, or equity in the licensing company. The license can be issued to an established company, a start-up, or a spin-off company. A spin-off is a company that is based on a technology or service derived from a parent company; typically, its first employees come from the parent organization.

Since the passage of this legislation, the labs became relatively comfortable with licensing intellectual property to large, established corporate research partners that fund research at the labs in exchange for access to the labs' vast intellectual capital and answers to challenging questions. The companies generally license any relevant intellectual property created for cash. However, research, intellectual property, and licensing interactions with start-up companies comprised a nascent skill set in the national laboratory system and introduced several new complexities to the existing R\&D and innovation paradigm. Start-up companies are often resource, especially cash, constrained and therefore work on very tight time frames and prefer equity rather than cash transactions. Spin-off companies, which are very popular in academia, are more challenging in the national lab system. At times technical staff leave the labs to form companies, often under the auspices of an entrepreneurial leave policy. Although "many spin offs have been successful, this process does not leverage the skills and knowledge resident in existing small firms to commercialize disruptive technologies, and can serve as a 'brain drain' on the laboratories, possibly impacting future developments in a particular area." [10] Also, in the national lab system, the lack of a significant pool of graduate students and post-doctoral researchers - who would be the most likely parties to form a spin-off company-make the spinoff an infrequently used mechanism for technology transfer.

There are many stakeholders in the process of technology transfer especially in the context of national labs; the stakeholders include the federal agency providing the funding, the lab operator, the licensee, and the public (Exhibit 4). Each party can have different metrics and expectations of technology transfer success. For example, is the technology transferred when it is licensed, when someone else invests in it, or when it is sold as a product? And what if the technology is successfully licensed but does not achieve commercial success; was it a technology transfer success? How should the parties prioritize the pressure to license technologies to companies versus creating solutions with the best chance of maximizing commercial and societal impact? These goals are not necessarily at odds, but there exists the possibility of emphasis on maximizing licensing transactions and revenue - possibly at the expense the public good.

\section{Ampulse History}

\section{Technology Identification}

Scientists at Oak Ridge originally developed rolling assisted biaxially textured substrates (RABiTS) in the mid-1990s for epitaxial growth of superconducting materials using crystallographically textured metal-foil substrates (Exhibit 5). Prior to the work at Oak Ridge, researchers were unable to grow crystallographically oriented superconductors because of a destabilizing chemical interaction between the film and the metal substrate. The Oak Ridge 
researchers had perfected the ability to grow a buffer layer on the top of the metal substrate that chemically isolated the growth film from the metal substrate while still transferring the underlying texture important for epitaxial growth. [11] The technology previously was licensed to 3M Company, Midwest Superconductivity, Oxford Super-Conducting Technology, MicroCoating Technologies, Inc., and EURUS Technologies, Inc. [12]

Glenn Kline, at Innovation Valley Partners-which was a \$35 million venture fund backed by "Eastern Tennessee business leaders" in Knoxville, Tennessee (less than ten miles from Oak Ridge) — was "struck by the [RABiTS] process and application opportunities and wondered if it could be applied to solar." He continued,

I saw how the solar market was developing films that could be provided in roll-toroll applications. RABiTS was one of the crown jewels of Oak Ridge's IP [intellectual property] portfolio but it was not seen as a venture deal. I wondered, "Could you use it as solar substrate?" If so, it would be [an] interesting opportunity, but Oak Ridge had no silicon deposition technology [which would be necessary for exploring photovoltaic applications].

To provide a route to using RABiTS for photovoltaic applications, Kline identified a suite of deposition technologies at NREL that looked like they might be able to solve the silicondeposition problem. NREL had developed a process called hot-wire chemical vapor deposition that could be used to grow a crystalline silicon film for photovoltaic solar cells and crystallographically oriented "epitaxial" silicon layers on silicon wafers. [13] However, hot-wire chemical vapor deposition was unproven for fabricating larger-scale solar cells and had not been used in conjunction with the RABiTS technology to grow crystallographically oriented crystal silicon. Kline approached the NREL Technology Transfer Office, which provided introductions to two NREL researchers, Howard Branz and Charles "Chaz" Teplin. Branz and Teplin already were pursuing growth of silicon on textured buffer layers, based on the superconductor model, but had not yet worked on RABiTS. Branz, Teplin, and Kline discussed the opportunity and the questions that had to be answered to determine whether these technologies could be combined for application in solar, and then developed a research program that would address those questions. Together, the research team and Kline developed a research agenda to address the underlying technical issues of combining RABiTS and hot-wire chemical vapor deposition. A Gantt chart of the first phase of the CRADA was developed to plan the research project (Exhibit 6), which was slated to begin in the first quarter (Q1) of 2008.

\section{Ampulse Corporation: A Virtual Company-A New Technology Transfer Model}

Kef Kasdin, general partner at Battelle Ventures (which was the affiliate fund manager of Innovation Valley Partners and co-investor in Ampulse) recalled, "Glenn was based in Knoxville and spent a couple days a week at the lab looking for opportunities. In this case, he identified a very deep set of technology expertise as well as many patents that had been applied to one set of problems." Kasdin continued, "We set up Ampulse as a virtual company to see if the combination of technologies could be applied to solar. This approach gave us large, varied, and defensible entry into the PV [photovoltaic] world."

Battelle Ventures is a venture capital firm located in Princeton, New Jersey. A description of its business and relationship to Battelle is provided in Exhibit 7. With the support of Battelle Ventures, Kline founded, funded, and took on the role of "acting CEO" for Ampulse 
Corporation. Ampulse originally was capitalized with $\$ 1$ million in seed financing from Innovation Valley Partners and Battelle Ventures at the beginning of 2008. A separate CRADA was executed with Ampulse and both NREL and Oak Ridge in less than a month.

Ampulse was a virtual company that aggregated the technologies across the two laboratories through an exclusive option to more than 30 patents that broadly protected the entire concept including materials, manufacturing technique, and product. Ampulse funded research at both laboratories to determine whether these technologies could be combined to create a superior silicon solar cell fabrication process; the potential benefits of the Ampulse technology over other silicon processing and proposed manufacturing benefits are summarized in Exhibit 8. At that time, Ampulse had no offices or employees, and all the company's money was able to go to research because there were no overhead expenses for staff or offices. In the virtual company model, Kline "metered out money to answer research questions with identified milestones." Kline also believed that "answering these questions up front allowed recruitment of a much higher caliber CEO in the future" because some of the technical risk was removed.

Because of Battelle Ventures' relationship to Battelle, "[it] has a strategic reason to try to find the opportunities at the labs and to fund these opportunities more than any other people but, at the end of the day, it still has to make financial sense for us to invest in a company," said Kasdin. In addition to its venture financing, Ampulse received \$900,000 from the DOE technology commercialization and deployment fund at NREL and Oak Ridge (Exhibit 9). Kasdin remarked on the importance of the commercialization funding,

Ampulse is the first project to take advantage of the [commercialization] funds from [the DOE EERE] at both Oak Ridge and NREL. We were really able to make our million-dollar investment go much further to develop the technology because we were able to cost-share the research.... Putting my "venture capital" hat on, the funds allowed us to justify the investment because we could stretch our dollars and reduce the technology risk in this very early-stage, very high-risk endeavor. We needed to prove that this was going to work, frankly, even before we could get other investors involved. It really helped us bridge that "valley of death.",

The virtual company model worked well to preserve capital, but it required both a significant time commitment and an operationally competent person to manage the business. Eventually Kline needed some help; at that stage he was introduced to Steve Hane. Hane has a successful background in telecommunications and data-communications in mid- and senior-level management positions at several firms, including venture-backed start-ups (see Exhibit 10, which includes biographies of Hane and other Ampulse consultants). After a successful exit from his previous company - and like many other entrepreneurs at the time-Hane decided to make a transition into clean technology. After joining Ampulse, Hane presented his thoughts on the renewable energy opportunity sector and his value as a seasoned entrepreneur (Exhibit 11).

\footnotetext{
${ }^{1}$ For more information on the "clean energy company valley of death," see L.M. Murphy \& P.L. Edwards, "Bridging the Valley of Death: Transitioning from Public to Private Sector Financing," NREL/MP-720-34036. Golden, CO: National Renewable Energy Laboratory, 2003.
} 
Hane had started working with Ampulse by consulting for Kline and helping him answer some of the questions that Kline had been unable to address. Hane valued helping Ampulse as a nonemployee because "as a consultant without an equity stake or other agenda, you can look at an opportunity completely objectively_look at all warts, look at all the positives — and make a decision about whether to get involved. I think it was an ideal way to find a deal." That consulting role slowly expanded over 4 months, and Hane was asked to assume the role of CEO in July 2008. Exhibit 12 shows a timeline of Ampulse's past and expected development when Hane took the reins.

Hane decided to take a position at Ampulse for a variety of reasons,

Ampulse is hopefully the first of many clean tech deals for me and I really viewed it as a way to build a systems approach to this new field for me. Working with Battelle, I'm closely aligned with folks who manage seven DOE national labs. As an entrepreneur, you want to have organizational connections that make you appear to have a presence much bigger than you really are. I saw that with Battelle.

By Hane's own admission, he joined Ampulse after the hard work required to assemble intellectual property and begin the research process was done. He reflected on Kline and Kasdin's early work to get Ampulse off the ground,

People don't give Glenn and Kef enough credit for how hard they work their deals. The reason they are so successful, regardless of the lineage from Battelle Memorial Institute and some of the connections that it provides, Kef and Glenn wear out more shoe leather than any VCs I've ever met. They work their way down the hallways [of the labs] to piece things together and make connections. There are a lot of VCs that come in and say, "Show us some things that we can make companies out of." That's just lazy. The way you find new ideas is to build trust relationships with the researchers that allow you to dig in with the teams, and learn what they are doing. Kef and Glenn and the rest of the Battelle team do that. These guys work their deals. And now that I'm CEO of one of their portfolio companies, I can say that that involvement doesn't diminish: [I]f I call Kef and say "I have a question for you about how we are thinking about ' $x$ ' decision," she will put down what she is doing and work on it. That's a very different relationship than just showing up every thirty days to the board meetings to gripe about something.

Kasdin viewed this hands-on approach as a strategic differentiator for Battelle Ventures.

I don't think many venture funds come to the [national labs] to actually fund research; most of them are looking for a technology that they can take out of the lab. The idea of funding research work in the lab to get to a certain commercially relevant milestone or set of milestones is new; I think we are pioneering that.

When he was hired, Hane was Ampulse's first and only employee. From his standpoint, there were several attributes associated with the "virtual model." 
The distinctive advantage certainly lies mostly with the VCs: They can place more bets because of the capital efficiency. The minute you add people, payroll, and benefits, you can burn through money fast. It's a fabulous way for a VC to get a good hard look at technical feasibility but it requires an agile player in that CEO role.

The control of the spending also affected the short-term scalability of the business and setting expectations was important. Hane said,

I would approach Battelle [Ventures] and say we don't have to put more money in but we do have to recognize by not putting it in and not doing these things what are we foregoing in terms of timeline and development of the company. Everyone around the table needed to agree that we're going to have a product out in March of 2010 instead of June of '09 because of a conscious decision not to pile the money in now because of the associated risk.

After he assumed the leadership of Ampulse, Hane worked diligently to develop the other parts of Ampulse business, not just the R\&D. Hane said,

Technologists ask me at the research meetings "Well, what are you going to do with your time?" [A]nd my job is to smile and go back to my office and work on everything but the technology. I think that anyone who is really great at what they do, like these guys are, tends to view the rest of the world like a support mechanism. The business of running a business is very unglamorous; it's health care plans and venture-debt instruments. None of it really is as glamorous as the fundamental technical concept.

Hane had developed a task-management system in the early stages that allowed him to keep track of things he needed to get done and to functionally assign them to roles in the virtual company (Exhibit 13). Another of Hane's jobs was to "nurture the close relationship with the lab." He continued, "Agendas that stay visible get serviced; my job is to say keep Ampulse visible."

That Hane spent his time on these non-technical things, however, was confusing to the scientists involved. At times, it seemed to them that, until the science was proven, it might just be a waste of money. Branz remembered,

Steve [Hane] told me straight out, there are four equal legs ... you start a company you have got to have all four legs for the table to stand up, you have got to have the technology, the money, the markets, and the people. If you are missing one of those four you are in trouble.... A scientist sees the main issue-whether the technology will do what we think it can-probably as three quarters of the problem. But it is only one of four equal legs to the startup. The size of the nontechnical investment, even in the early stage, would surprise most scientists.

Teplin agreed,

[I]f you can actually make a technology that could transform the world, like this one could, it seems like the only thing that matters to me is the technology. It's 
crazy to me to worry about whether or not you have vendors lined up for the first 6 months before you even prove it technologically. This is energy, the biggest business in the world. If a company is successful, we're talking Exxon-like revenue. ${ }^{2}$ Prove the technology and the rest will come. This would be the ultimate NREL success story!

\section{NREL Researchers}

NREL is a world-leading research and development organization for energy efficiency and renewable energy technologies. Photovoltaics, in particular, are an area of strength. NREL currently holds the world record for photovoltaic cell efficiency across many different technology areas (Exhibit 14) and played an important role in developing many of these technologies. However, NREL's expertise in these examples is focused on developing record high efficiencies in lab-scale solar cells, not in translating these efficiencies to commercially relevant, deployable solar modules. The laboratory regularly produces publications and patents that help disseminate technical information to the public (Exhibit 15).

NREL researchers Howard Branz and Chaz Teplin were involved with the Ampulse project. Branz was a principal scientist and the manager of the Ampulse project. He received his Ph.D. from MIT in 1987 and immediately went to work at NREL; since then, he has had a very successful scientific career and has delivered more than 300 publications and presentations. Branz spent about $20 \%$ of his time directly on the Ampulse project and about $50 \%$ on related projects. He was just finishing 5 years managing the Silicon Materials and Devices Group at NREL and, as a manager of that group, he had worked with several companies on collaborative research projects. He had stepped back from that role because he wanted to do more research and have more direct involvement in answering scientific questions and improving photovoltaic devices. Branz also noted that several of his colleagues joined start-up and established solar companies, and he wondered if this was a more effective route to transfer his knowledge to the outside world.

Chaz Teplin also is in the Silicon Materials and Devices Group. He joined NREL as a postdoctoral researcher after receiving his Ph.D. from the University of Colorado at Boulder, and was recently promoted to senior scientist. Since joining NREL, Teplin has coauthored more than 30 presentations and publications. Through the directly funded Ampulse project, as well other projects that indirectly supported the research, Teplin essentially worked full-time on Ampulse and related projects.

Public presentations and publications are important to scientists because these comprise one of the most important measures of the stature of the scientists in the scientific community. Branz explained:

The conventional wisdom is that the number of invited talks and publications [is] a scientist's currency, with which you purchase the raw materials of your research, including the best post-docs, the best collaborations, and of course the money. So, these invited talks allow you to go out do the best possible research

\footnotetext{
${ }^{2}$ In 2008, Exxon Mobil Corporation (NYSE:XOM) had gross profit of more than $\$ 95$ billion on revenues of $\$ 477$ billion (http://www.google.com/finance, accessed May 6, 2009).
} 
and, like in any business, you try to grow it. There's another theory that says the science community is something like a Native American society, where the way you increase your prestige is to have enough valuable things so you can give gifts to everyone. The presentations and papers are the gifts and giving gifts raises your prestige, which allows you to do more, and allows you to be able to give more. At a conference or in the literature, you differentiate yourself by the quality and quantity of the gifts you are giving to the community. The magnanimity and the quality of the gifts you are able to give comes from your intellect and also from these other things you've collected, your post-docs, collaborators, etc.

This is very different than the model that's operating in the start-up companies, which is to hide everything. It's all about holding things close, it's about moving things fast whether they work or not. You may give out a few gifts to build interest but not enough to give away the secret of how it works. And you may push to create gifts that look better than they are. But the problem is if I have control of most of the elk that were just killed for the winter and I then give it out and it turns out to be rancid and makes everybody sick, that's not good for my status, right? So the stuff that I am doing better be right: [T] here is a very high premium on being right and having things work in science. In the venture-funded company there is also a high premium on having this [technology] work but there is a higher premium of getting in the next round of funding, which is not always the same as making things work.

Both Branz and Teplin wanted to see the knowledge they created somehow be transferred to society. They often accomplished this via peer-reviewed journals. Ampulse had asked to review publications before submission to make sure that the documents did not disclose the inventions, but this control of publication was difficult for the scientists professionally because of their priority for objectivity and intellectual honesty. Publications in refereed journals also were thought to be the least effective means of technology transfer and provide the least support for the ultimate commercial success of Ampulse. [14] Both researchers therefore also were committed to helping protect intellectual property developed during the research project, and had filed several records of invention (ROIs). Sometimes the ROI submissions and the time that NREL took to review the intellectual property also could delay publication, which could become frustrating for researchers.

Ultimately, the NREL researchers enjoyed the Ampulse project and had deep respect for all the parties involved. Teplin said, "Everyone has generally demonstrated a high level of confidence and competency at their jobs, so I've never felt like we've been misled. Even though their perspectives may be different from my own, I can understand how the different parties [Ampulse, NREL, Battelle] have acted based on their viewpoints." It was a difficult challenge for the scientists to work on a project like this, however, which according to the typical venture model had a low probability of success because "there exists a built-in environmental conflict between governmental and market influences." [2]

Branz reflected:

There is a big cultural mismatch that people don't actually talk about: Scientists working for the Department of Energy really have developed a low tolerance for 
risk because of the way we are managed. We are managed heavily on milestones and it is considered unusual here when people miss a milestone; if you don't meet your milestones you get hassles. Therefore, people are in the habit of picking their milestones very carefully. If they do work on high-risk stuff, they set it aside and never tell anybody about it-they do it in secret. That's a strange culture for developing relationships with entrepreneurial ventures that have a relatively low success rate. Typically in our [DOE-funded] research we are aiming for 80 to 90\% success and people get in the habit of that. Then, if we're asked to work on something that might have a[n] 80 to $90 \%$ failure rate [such as a start-up company], that's a really difficult shift in mind-set. And if it fails we are not going to be able to give something of value into the scientific community. In the companies, the scientists might be motivated by the potential for financial reward but I'm not sure that motivates the national average of scientists strongly; we tend not to have a great desire to get rich. The scientists want to spend their careers on things in order to make their reputations, to be able to have technical success, and to be able to give gifts to their community of scientists. So a risky venturebacked research project that might distract a scientist from typically funded projects might constrain his ability to publish, and he's not going to get rich. ${ }^{3}$ [W]here's the scientist's motivation?

Kasdin agreed, "There is a difference in how these deliverables and milestones are perceived. It's important to set the right expectations with the research team about these kinds of programs and everyone needs to be on board that they are very different from a DOE program: commercial milestones, entrepreneurial timeframes, ${ }^{4}$ etc."

Teplin had a slightly different perspective on his motivations:

If we succeed and make a great product that can go to market in a rapid time frame then everybody wins. Having fun and getting to play a role on something that might work is probably the most important to me. In some sense, as long as I can make a living, that's great. If I have some financial benefit from it or my specific technology wins, even greater, but that's not really what really drives me particularly hard anyway. Publishing and patents and all those things are nice for sure but I have barely published since the Ampulse collaboration started. I certainly care about it: I enjoy writing papers and I like seeing my name cited but publications aren't necessarily my goal.

In fact, Teplin also was motivated by something that brings many people to NREL: The opportunity to "make the world a better place" by being a part of the solution to global warming (Exhibit 16). Hane also spurred Teplin by asking him if he would rather see his name on a paper

\footnotetext{
${ }^{3}$ Similar to many other nonprofit organizations such as universities, the operating contractors of the national laboratories were able to patent, license, and generate revenue from intellectual property created through federally funded research and resultant technology transfer activities. This revenue often was split between the named inventors, the research center or department, and the organization as a whole.

${ }^{4}$ To quickly create enough value to satisfy the risk associated with the venture, start-up companies-especially those that are venture backed-must move very quickly to realize the required company growth. This is starkly opposed to the government and its affiliated institutions, which often are characterized by bureaucratic and slow-moving organizations.
} 
at a conference or be able to buy a roll of the solar panels that he helped create from any Home Depot.

Teplin continued his reflection, "I often wonder if Ampulse's goals and my goals aren't necessarily the same. Fundamentally, I hope so. But it's not Steve's job to care about my goals. It's Steve's job to try and keep me motivated for Ampulse's goals." In many ways, Hane agreed with Teplin,

In one sense I have to ignore the fact that [the researchers] have those other duties [to DOE and other research partners]. I have to be cognizant of it because it's always the backstop of me getting more of their time but it's my job to have them focused on Ampulse as much as I can. . . Most people who interface with the labs on CRADAs don't know where those boundaries are and you only get to really know that by interacting with the team closely. ${ }^{5}$

\section{Research and Development}

Before Kline approached the lab, NREL researchers had applied for patents on their technology and were busy presenting their work for conferences. The Ampulse CRADA allowed Branz to have access to the substrate and to try to grow solar materials with the epitaxial process. Teplin remembered, "Basically, Glenn [Kline] provided money to make that [research] happen and accelerated it. We could have gone to Oak Ridge and said 'Hey, let's try and collaborate' but that takes time and money."

Ampulse had successfully garnered support from a variety of different sources and had several stakeholders engaged in its success. Hane remarked, "This is a great story of turning a fundamental taxpayer-funded investment in research [most of the intellectual property that Ampulse had optioned was from federally funded research and development] into a commercial outcome that could really positively affect society." However, Branz and Teplin were cautious to balance the high visibility and riskiness of this project with their other funded research. Teplin said, "It would suck to put all our eggs in the Ampulse basket and have Ampulse fall apart and then DOE say, 'Well, this whole research program on film silicon doesn't work' and then cut our funding." The technical questions that came up during the course of the project made Branz acutely aware of his role straddling two priorities: To help Ampulse move forward, and to objectively advise NREL and DOE about the realities of the project. He considered the potential importance — to his whole career — of maintaining that objectivity, "Even though we are working like crazy to push this thing forward, I just feel like it is my responsibility . . . to tell everybody what the technical odds of success are. Our reputations die if we make things up, and that's permanent, but if this thing dies the VC just moves on."

\footnotetext{
${ }^{5}$ Depending on the modes of interaction between technology transfer partners, close spatial distance between partners could help lead to successful partnerships. However, this is not the result of just being located close to each other. The spatial distance of technology transfer partners allows for more meaningful exchanges in which the technology developers understand the values, motivations, and biases of their corporate partners and vice versa. This understanding, or "cultural proximity," actually is the value that correlates with a greater chance of technology transfer success (see M.M. Crow, "Technology and Knowledge Transfer in Energy R\&D Laboratories: An Analysis of Effectiveness." Eval. Program Planning. Vol. 11, 198; pp. 85-95).
} 
Many entities already cited Ampulse as a success for getting the technologies out of the lab. Hane, however, questioned the different parties' perspectives on Ampulse being a success story for commercialization:

We're trying to do something really important by bringing this solar technology to market and we need to hang a win on the wall. But, for me, commercialization is not licensing a technology out of the lab or a production-ready product. For this to be a success, I have to secure my first consumer and for Ampulse that comes in early 2011. We will be able to call Ampulse a commercialization success when either we have revenue flowing or there's an exit for the company.

The CRADA outlined three distinct research phases that Ampulse, NREL, and the Oak Ridge National Laboratory would proceed through. ${ }^{6}$ The completion mark of the first phase of the CRADA was a "lifetime measurement." Teplin recalled,

Glenn said, "We need to demonstrate lifetime on silicon." But at that time we couldn't even demonstrate that we could grow the right material! So for the first 6 months, we spent most of the project trying to grow the right phase of silicon. When we finally actually did it, I was like, "Whoa, home run-great publication!" But [Ampulse] wanted to measure the lifetime and that was another huge step. We are supposed to meet this lifetime measurement milestone in order to get the round of next funding, but I look at the technology and say there are other real challenges here and here. There's never been that much disconnect between the milestones and budget. But we've never actually met a milestone-we've made a lot of technical progress, but we've never actually met the original milestone of a lifetime measurement [at the level needed for a good solar cell].

Branz said,

The management at DOE and NREL think that there is a mismatch at the desired rate of work on this kind of project. That may exist at times because the lab and company have different amounts of management oversight, bureaucracy, and other barriers-but I don't think that's the real problem. The biggest challenge in working together is the cultural mismatch: [T] he willingness to tolerate risk, to tolerate wasted time, to tolerate being wrong.

Hane quickly realized that he was significantly out of his depth in terms of technical competency, and felt he was having a difficult time discussing the technical milestones with the NREL research team. Hane brought on Paul Schroeter as acting COO/consultant in late 2008 to ameliorate this situation. Schroeter was an excellent addition to the team for a variety of reasons. Hane said,

Paul has a track record of going from that hairy edge of an $R \& D$ project to a full factory that can make 500 million dollars worth of this stuff in a year. He's done that from the ground up all over the world. Simultaneously, he has this unique ability to empathize and understand why $R \& D$ people are wired the way they are

\footnotetext{
${ }^{6}$ There was no performance clause in the CRADA. Ampulse was billed directly for the time and resources spent working on the project that was targeting the stated research goals.
} 
and help craft research programs that address their goals as well as the company's goals. He can talk technical details with these guys much better than I can, and at the same time he's got the gears turning in his head about "[H]ow do I make a factory," "[H]ow far in advance do I need to start making [deposition] reactors, "etc.

Teplin agreed with the positive perceptions of Schroeter's involvement,

Paul is basically running Ampulse's version of the technology management and he has done a good job. He has forced us to design experiments in different ways that really answer questions differently, in a commercial direction. He's put pressure on us to get more experiments done in a shorter timeframe. We normally keep control of our own schedules so that we can manage multiple projects. But he's forced us to detail every aspect of running an experiment and has extrapolated the possible number of runs we could do in a week. We all know when we're working at capacity and when we're not. It's also allowed us to work towards transferring some of the deposition work to an engineer. Another great thing he's done is that we have this valuable experimental tool that typically runs about 20 to 25\% of time because we work 8 hours a day and we have lots of meetings and we take vacations. Paul says "I'll pay somebody to run it at night." He's right! Howard and I had the initial response that that's impossible at NREL and then we had to rethink . . it and found that maybe it wasn't impossible, so we started moving along to see if we could get that to happen. It's a half-milliondollar piece of equipment, it makes perfect sense to hire somebody for $\$ 50,000$ a year and get it running around the clock-not just for the amount of data that we could generate but it's a much better use of taxpayer dollars that paid for the equipment.

Schroeter brought a unique research perspective to the Ampulse project; one that he had developed during his 30-year career in industry. Rather than taking one piece of data and trying to explain it from many different directions, Schroeter wanted to map out thousands of data points and try and understand trends that the data elucidated. Although this is a very effective use of the NREL equipment, it was not really of interest to the NREL researchers. Consequently, Ampulse planned to pay a researcher to work in the NREL labs "to turn the experimental crank" and Branz and Teplin would review those data generated. Hane said,

Frankly, I am tapping into the best available intellect on these particular topics. However, that's a separate issue from [whether] the scientists are entrepreneurial or good engineering project managers. I cannot and should not expect them to be those other things. But I also need those attributes represented when we move from science to engineering. The fundamental breakthrough is elegant and exciting, but engineering it to replicable scale is less intriguing work. We've tried to pioneer here by getting our own people inside the lab to be able to separate the issues of data generation and data analysis. Ampulse technologists will help run the reactors around the clock and generate results for the NREL experts to interpret. There literally has to be a seamless feel between who is working at NREL and who is working at Ampulse for this project to work. When it comes 
time to hand out the work for next week, it's not two sides of a table, it's a work team around a circular table.

In addition to the personnel working with the labs, Hane had access to an "incredible physical asset." He said, "The types of analytical gear ${ }^{7}$ that we can run our samples through [is] beyond practical replication even for large companies. If we were doing this completely on our own I would be sending things off to labs and spending lots of money waiting for results."

\section{Financing}

Ampulse had slightly more than $\$ 500,000$ remaining when Hane assumed his role as CEO in July 2008. Hane expected to achieve the key technical milestone-good enough lifetime measurements to guarantee a good solar cell (or, equivalently, good diffusion length) — within a few weeks of taking the helm. This milestone was a major proof-point for the technology and company, and Hane anticipated launching a serious Series A campaign in the first week of September. But this anticipated milestone continued to slip. At the end of September, because of delays in getting the good lifetime measurements (which then were expected in October), Hane decided to delay the Series A capital raise until the just after the New Year. It wasn't until January 2009 that technical advances made by the collaboration enabled the NREL scientists to obtain respectable lifetimes on tiny areas of Si grown on RABiTS, but they had still had not achieved the milestone lifetime from an entire film. These delays had a significant impact on Ampulse. Hane was more than half a year delayed in raising his Series A round, and he still didn't have the technical data points that he thought were necessary to raise a venture Series A round at a good valuation.

Hane remarked on the effect of this slip on research deliverables on the viability of Ampulse,

Today [January 2009], the story of our development is short of where we thought we would be right now. For a host of good reasons, we had challenges and they took time to solve and they all make sense. But the outside world doesn't care if the reasons are good or ... bad, all they know is that you said this a year ago and now here's where you are and so what's the story. Every completed milestone builds credibility and says "you can put money on that because they are doing what they say they are going to do." A slipped milestone means in a practical sense first of all lots and lots of explanation to the investors as to what's going on. The second thing it puts in jeopardy is your ability to raise additional money because you don't have the credibility.

Kasdin-Ampulse's seed financier-was sympathetic, "Stuff happens in technical development and some of the reasons for the slips were explainable. There were just some unanticipated consequences. We were managing a complex development project across two labs with busy researchers and things happen." Other venture capitalists that Hane spoke with were less sympathetic. Some told him that they would not fund a company in which all the technical work was being done inside the national lab because Hane did not have enough control of his research

\footnotetext{
${ }^{7}$ NREL has a large campus with facilities and cutting-edge experimental equipment that is used by NREL researchers as well as external CRADA partners. Most of the equipment is paid for by the DOE and represents a significant investment. A private company would have to spend hundreds of millions of dollars to recreate NREL's physical plant and the resources it contains.
} 
team. Hane was very cognizant of the effect of this inability to secure financing on Ampulse's future. He said,

If we don't secure financing, I close the company down and everyone who is associated with the company is out of work and it will take me another 6 to 9 months to find another CEO job. Regardless of the past successes that I've had, I want to work and I need to work, I have three kids going into college, so I'm not okay if it goes down. While I know [the NREL researchers] have their reputations hung on Ampulse too, if this thing fails they get to keep their jobs and funding and keep on going, business as usual. I do think the stakes are higher for the entrepreneur.

Kasdin remembered,

When Steve joined, I think he was thinking that all the research would come in as planned and he had sort of teed himself up to start going out and talking to the venture community as early as September. He presented at a couple public forums and was essentially already kind of out there. He didn't say much, but he did say enough to whet people's appetites, and I think we had some very good receptivity. We were waiting to hit all these milestones to take out some risk and increase the valuation, but then we get to January we haven't met those milestones. So, what do we do? Do we go and tell people well we didn't get as far as we wanted to but we are going to start raising money anyway? Or do we say well, no, we've really got to meet this milestone first?

\section{Hane's Dilemma}

In January 2009, Hane was at a crossroads. He knew that he had all the ingredients for successa supportive financier, a talented research team, and "a solar technology that can conquer the world." By delaying hiring Schroeter and making a couple other strategic moves, he had been able to stretch his cash to keep from having to do a capital raise while the research teams still were working on the technology. But he was going to run out of money soon.

Hane reflected on working with the national labs,

You have to be pleasantly relentless working on a collaborative project with the national labs, and you can't rely on the CRADA alone to run the [research] project. If you do, you're trying to steer the Queen Mary with a canoe paddle. But, if you are willing to invest in communication and teamwork, the national lab environment will stagger your imagination with its possibilities. 


\section{References}

[1] U.S. Department of Energy. National Laboratories and Technology Centers. http://www.energy.gov/organization/labs-techcenters.htm. Accessed May 4, 2009.

[2] Crow, M.M. "Technology and Knowledge Transfer in Energy R\&D Laboratories: An Analysis of Effectiveness." Evaluation \& Prog. Plan.; Vol. 11, 1988; pp. 85-95.

[3] http://www.battelle.org/ABOUTUS/vision.aspx. Accessed January 27, 2010.

[4] Bozeman, B.; Fellows, M. "Technology Transfer at the U.S. National Laboratories: A Framework for Evaluation.” Evaluation \& Prog. Plan.; Vol. 11, 1988; pp. 65-75.

[5] Bozeman, B.; Crow, M. "Technology Transfer from U.S. Government and University R\&D Laboratories." Technovation; Vol. 11(4), 1991; pp. 231-246.

[6] Bozeman, B.; Coker, K. "Assessing the Effectiveness of Technology Transfer from U.S. Government R\&D Laboratories: The Impact of Market Orientation.” Technovation; Vol. 12(4), 1992; pp. 239-255.

[7] Rogers, E.M.; Takegami, S.; Yin, J. "Lessons Learned about Technology Transfer." Technovation; Vol. 21, 2001; pp. 253-261.

[8] Kearns, D. "Federal Labs Teem with R\&D Opportunities." Chem. Engineering; Vol. 97(4), 1990; pp. 131-137.

[9] Bodde, D.L. "On Guns and Butter: Reflections on Technology Transfer from Federal Laboratories." Technology in Society; Vol. 15, 1993; pp. 273-280.

[10] Kassicieh, S.K.; Kirchhoff, B.A.; Walsh, S.T.; McWorter, P.J. "The Role of Small Firms in the Transfer of Disruptive Technologies." Technovation; Vol. 22, 2002; pp. 667-674 (including references).

[11] Norton, D.P.; Budai, J.D.; Goyal, A.; Lowndes, D.H.; Kroeger, D.M.; Christen, D.K.; Paranthaman, M.; Specht, E.D. "Low-Cost Metal Substrates for Films with Aligned Grain Structures." First Conference on Future Generation Photovoltaic Technologies. Denver, CO. 1997.

[12] Oak Ridge National Laboratory. www.ornl.gov/info/ornlreview/rev32_3/awards.htm. Accessed January 29, 2009.

[13] Teplin, C.W.; Branz, H.M.; Jones, K.M.; Romero, M.J.; Stradins, P.; Gall, S. "Hot-Wire Chemical Vapor Deposition Epitaxy on Polycrystalline Silicon Seeds on Glass." Material Research Society Symposium Proceedings. Vol. 989. San Francisco, CA. 2007.

[14] Gibson, D.V.; Smilor, R.W. "Key Variables in Technology Transfer: A Field-Study Based Empirical Analysis.” J. Eng. Technol. Manag.; Vol. 8, 1991; pp. 287-312. 


\section{Exhibits}

\section{Exhibit 1: U.S. Department of Energy national laboratory system.}

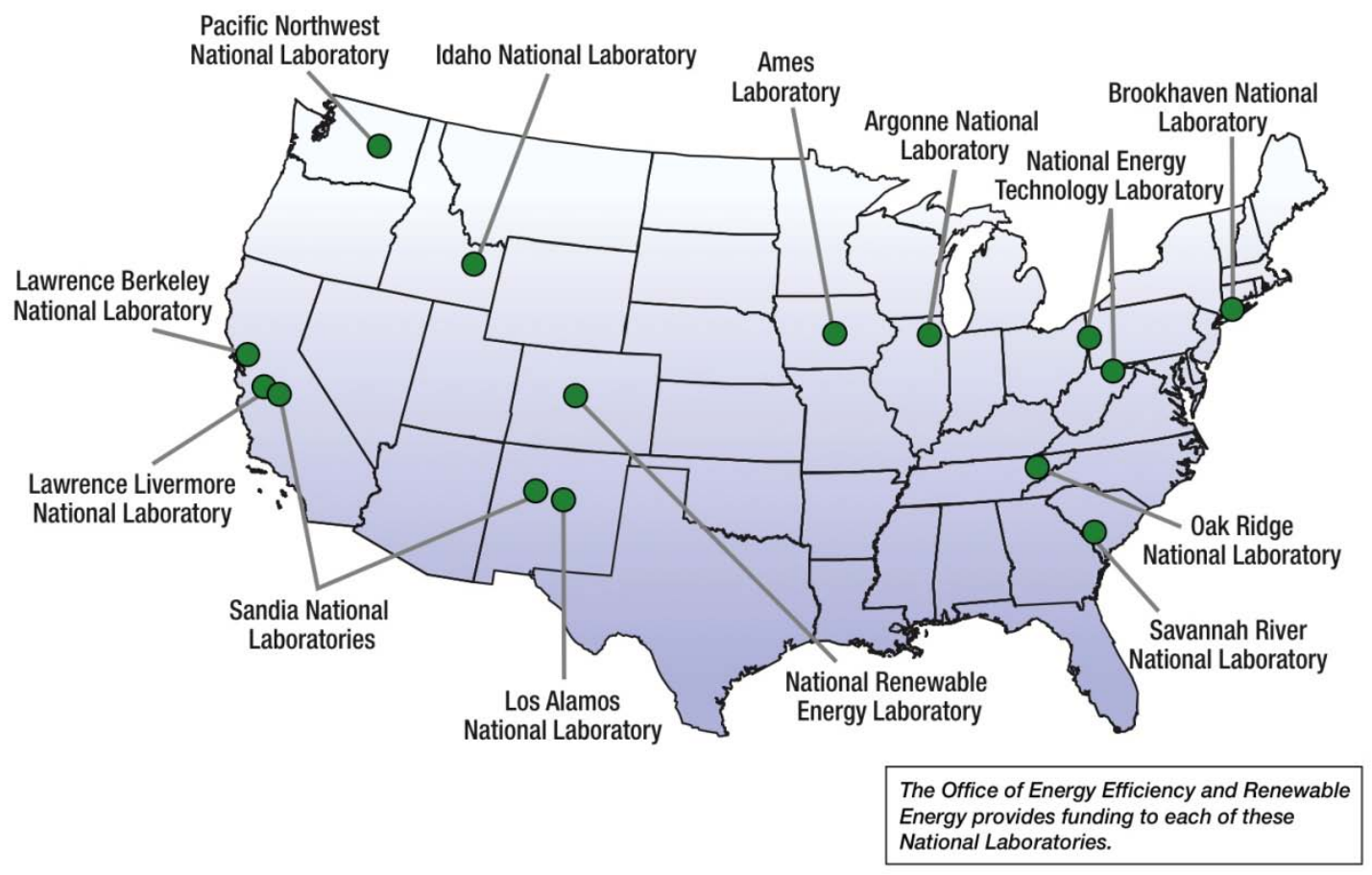

Source: http://www1.eere.energy.gov/commercialization/nationallaboratories.html, accessed May 4, 2009.

Exhibit 2: Battelle Memorial Institute lab management page.

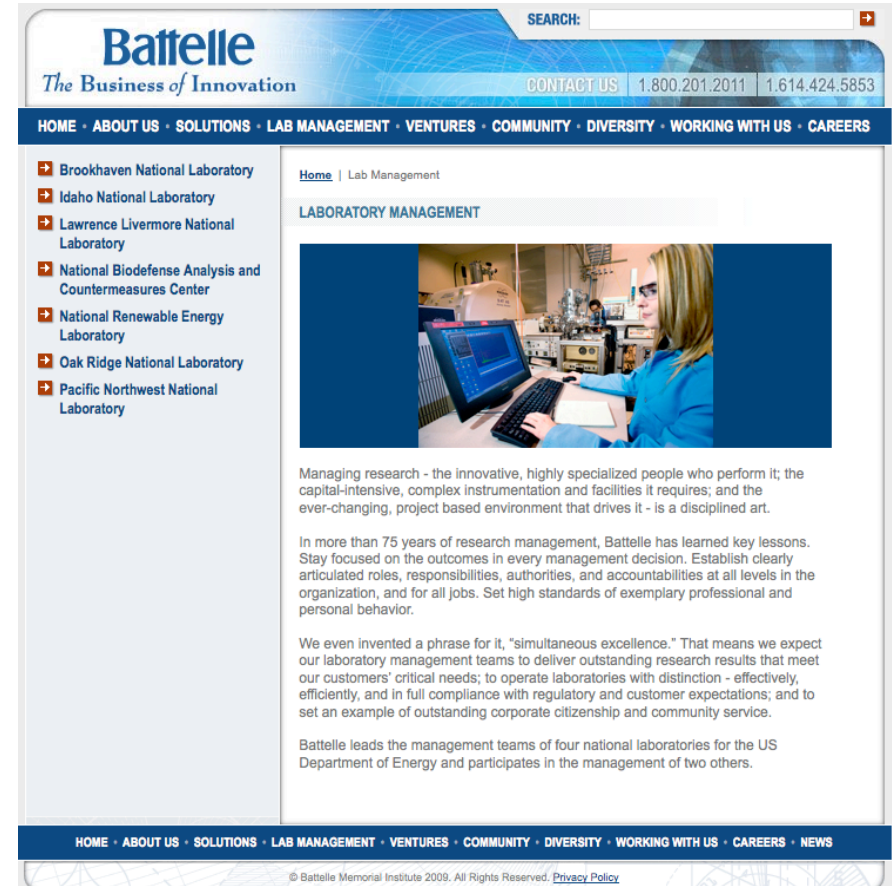

Source: http://www.battelle.org/labmanagement/index.aspx, accessed May 4, 2009. 
Exhibit 3: NREL FY2009 program portfolio.

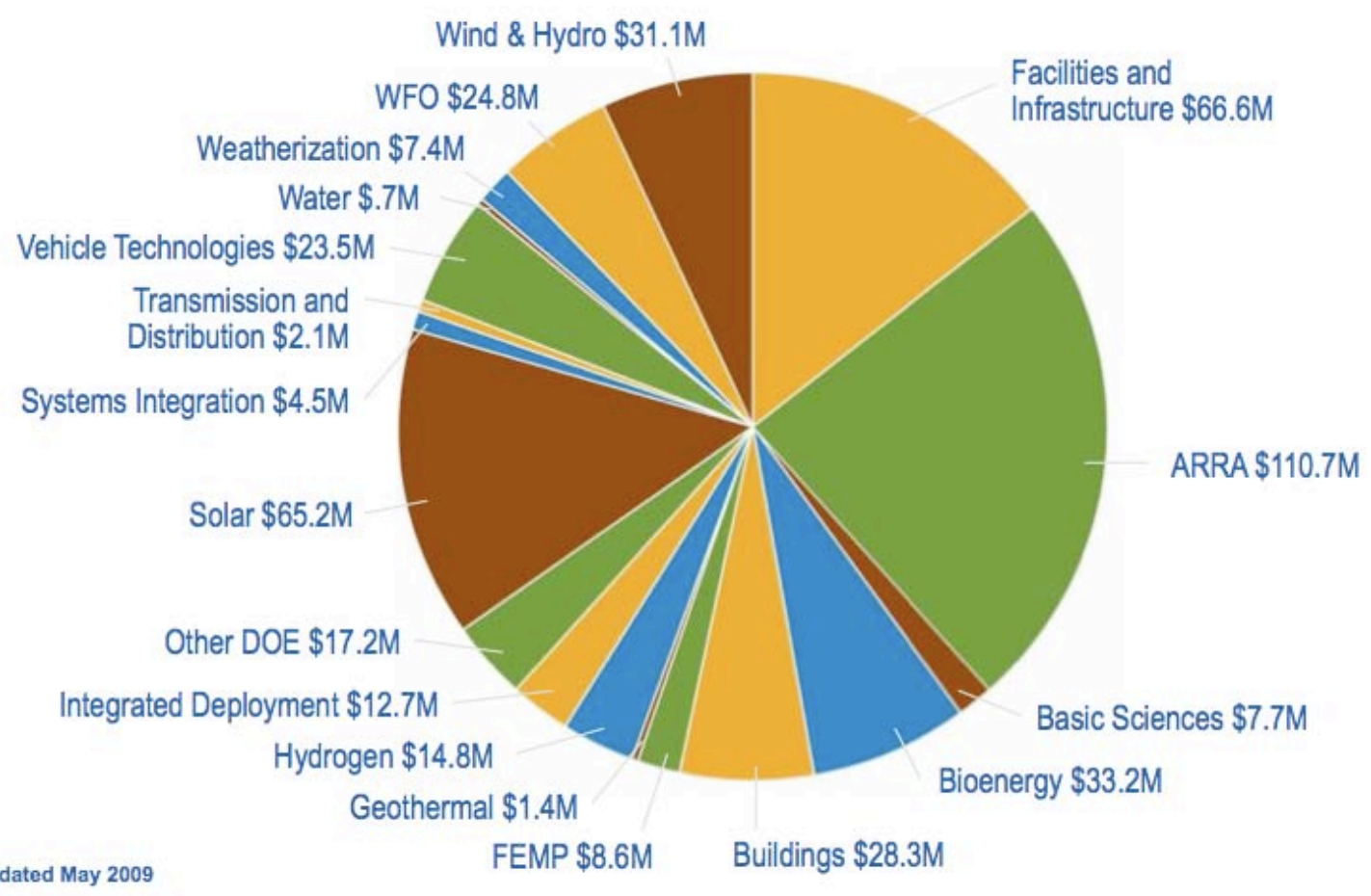

Source: NREL.

Exhibit 4: Intellectual and financial capital flows related to intellectual property at the national labs.

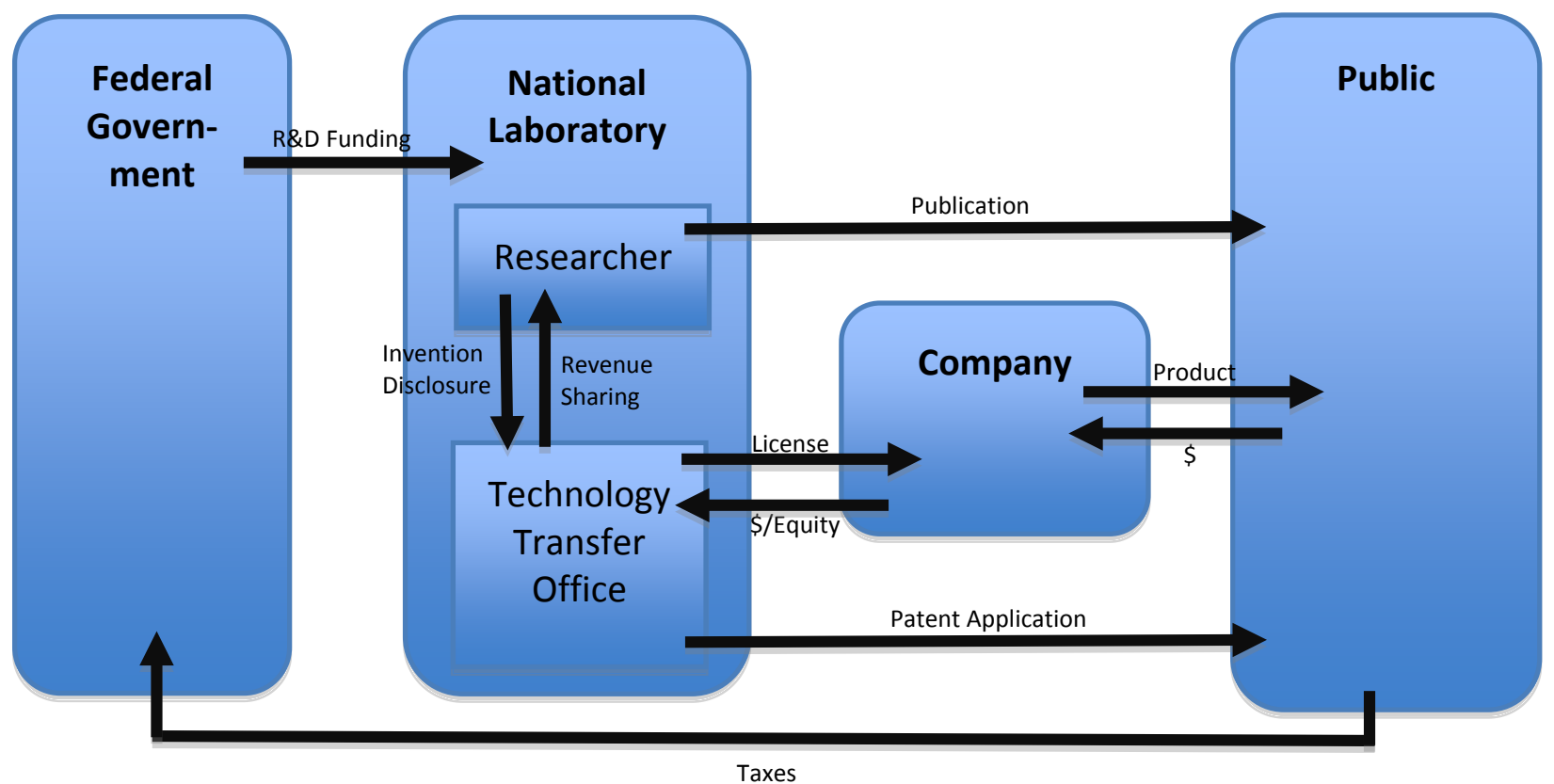

Source: Casewriter. 


\title{
Exhibit 5: A description of the RABiTS technology.
}

\author{
High-Temperature Superconductivity Fact Sheet — Oak Ridge Simplifies RABiTS Fabrication
}

A new substrate for $\mathrm{YBa}_{2} \mathrm{Cu}_{3} \mathrm{O}_{\mathrm{x}}$ "coated conductors" developed at the U. S. Department of Energy's Oak Ridge National Laboratory has been produced using common industrial coating equipment. The substrate offers the promise of affordable, second-generation, high-temperature superconducting wires for the emerging multi-billion dollar electric power equipment market. The coated conductor concept uses a metallic nickel foil, two ultra-thin ceramic layers, and a layer of yttrium-based high-temperature superconductor on top. Superconductors can carry large amounts of electric current without losses due to resistance. High-temperature superconductors can perform this feat above the relatively "high" temperature at which liquid nitrogen boils, 77 Kelvin (minus 321 degrees Fahrenheit). The tape's appeal lies in its simplicity and potential low cost and high speed of fabrication. The ceramic layers on the substrate can be made on equipment that's similar to that used to produce labels on soft drink cans, audio and video tape, and even the liners inside snack food bags. In order to make the substrate work, however, extremely thin oxide layers must be put down uniformly, and in such a way that their crystalline structure mimics almost exactly that of the nickel metal tape.

"'[Oak Ridge's] result represents a major step forward in the development of its new superconducting wire technology," said Bob Hawsey, director of Oak Ridge's Superconductivity Technology Center. The basic idea is called "RABiTS," for rolling-assisted, biaxially-textured substrates. The Oak Ridge group recently produced the substrate using a simple buffer layer architecture and a common industrial film growth technique, called electron beam evaporation. The resulting sandwich of materials can then be used to grow high-quality layers of the superconducting materials that actually carry the electric current. Earlier (in 1996), Oak Ridge demonstrated the production of RABiTS using pulsed laser deposition to grow the buffer layers. High critical current densities were produced using this substrate. Commercial developers were faced with the double challenge of scaling up the way to make the substrate and learning how to grow the superconductor on that substrate, all with limited dollars.

For the last few years, the ability to use the new high-temperature superconductors at the relatively "high" temperatures which their namesake implies (that is, liquid nitrogen's boiling point of 77 Kelvin, or minus 321 degrees Fahrenheit) has been limited. At this temperature, even weak magnetic fields as low as a few thousand gauss can virtually destroy the superconductivity in some superconductors. These are the levels of magnetic field that are present in most electric machines, such as transformers, motors, and generators. The field produced by neighboring wires in a transmission cable can also adversely affect its performance.

Electron beam evaporation technology and RABiTS may change all this. What Oak Ridge has done is to produce a new, industrially-scalable template on which the superconductor may be deposited. First, pure nickel is roll-textured and heat treated. Next, extremely thin layers of two ceramic materials are rapidly deposited at Oak Ridge using a laboratory-scale electron beam system. For this, a cerium oxide layer as thin as 100 angstroms is placed "almost instantaneously" on the rolled nickel, followed by a 1400 angstrom layer of yttria-stabilized zirconia. In the lab environment, this layer takes about 20 minutes to grow. The buffer layers produced to date have excellent microstructural characteristics. The ceramic layers in the RABiTS sandwich are remarkably thin. A typical sheet of copier paper is about 500,000 angstroms (0.002 inch) thick. These buffer layers are, therefore, 350 times thinner than a sheet of paper. Oak Ridge staff member M. "Parans" Paranthaman did the electron beam evaporation of the two buffer layers. A paper describing these results is in press (Physica $C$ ).

Hawsey said that their recent accomplishment could be just the thing to push superconducting wires into the industrial and electric power sectors of the economy. "While others have been tackling the difficult issue of scaling up superconductor deposition on these kind of substrates, Oak Ridge wanted to see just how simply we could make the RABiT substrate that these companies need for good wire properties. We think that the latest results represent a step in the right direction." Early results from growing superconductor on the substrates are encouraging. Oak Ridge staff member David Norton used pulsed laser deposition to grow the superconductor on the newest version of RABiTS. One sample, a 3-mm (1/8 inch) wide tape, carried 18 amperes of current at 77 Kelvin and 50 amperes at 65 Kelvin, measured across the full tape width. The new tape's performance as a function of temperature and applied magnetic 
field was similar to that obtained earlier using buffer layers deposited entirely by the laser ablation process. The preparation of additional samples intended to duplicate this result is under way.

Oak Ridge's tape conductor research program is funded by two offices at the U. S. Department of Energy: The Office of Energy Efficiency and Renewable Energy's Office of Utility Technologies, and the Office of Energy Research's Office of Basic Energy Sciences. Dr. James G. Daley, team leader for the DOE Superconductivity Program for Electric Power in the Office of Utility Technologies, commented that "the Oak Ridge approach to substrates for YBCO coated conductors appears to offer attractive cost and performance advantages to wire developers.

Source: http://www.ornl.gov/sci/htsc/documents/archives/factsheet.htm, accessed Oct. 9, 2009.

Exhibit 6: Original research and development Gantt chart.

\begin{tabular}{|c|c|c|c|c|c|c|c|}
\hline Activity & Time & Month 1 & Month 2 & Month 3 & Month 4 & Month 5 & Month 6 \\
\hline Screen Lit. \& identify best materials & 0 to 1 & & & & & & \\
\hline Specify sample handling & 0 to 1 & & & & & & \\
\hline Dev. surface treatment for lifetime test & 0.5 to 4 & & & & & & \\
\hline Dev. deposition plan for heteroepi & 0 to 1 & & & & & & \\
\hline Receive ( $12 \times 5$ materials) samples from ORNL & 0.5 to 2 & & & & & & \\
\hline Test diff. barrier integrity & 0.5 to 2 & & & & & & \\
\hline Deposit test heteroepi & 1 to 6 & & & & & & \\
\hline Characterize with XRD, RTSE, AFM & 2 to 6 & & & & & & \\
\hline Selected TEM and EBSD & 2 to 5 & & & & & & \\
\hline Patent any novel IP & 4 to 6 & & & & & & \\
\hline Measure minority carrier lifetimes & 3 to 6 & & & & & & \\
\hline Hydrogenate and RTA best materials & 3 to 6 & & & & & & \\
\hline Mechanical test at ORNL & 4 to 6 & & & & & & \\
\hline Write report on progress & 5 to 6 & & & & & & \\
\hline Revise Phase II & 4 to 6 & & & & & & \\
\hline & & & & & & & \\
\hline & & & & & & & \\
\hline & & & & & & & \\
\hline
\end{tabular}

Source: H. Branz, May 4, 2009. 
Exhibit 7: Extracted pages from the Battelle Ventures web site.

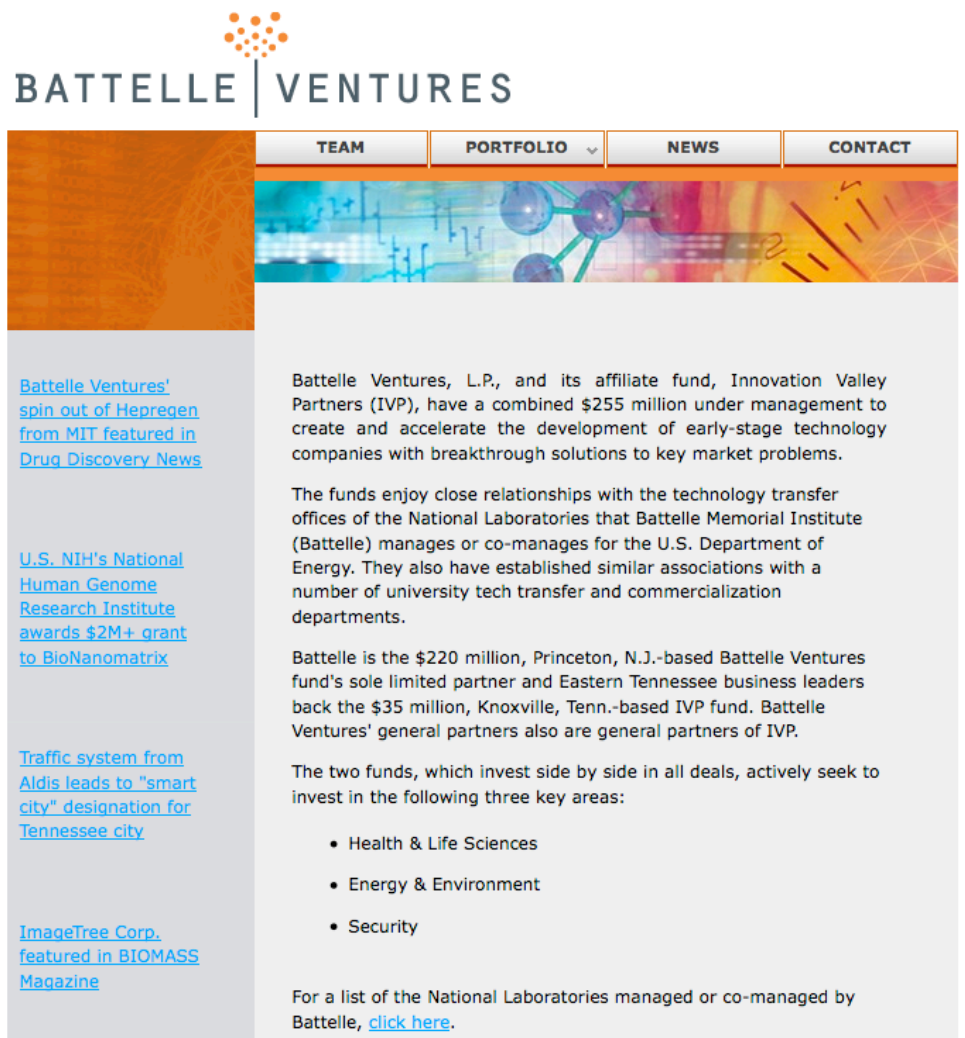

Source: http://www.battelleventures.com/, accessed May 4, 2009.

BATTELLE |VENTURES

\begin{tabular}{l|c|c|c|c|}
\hline HOME & TEAM & PORTFOLIO & NEWS & CONTACT \\
\hline & &
\end{tabular}

Battelle Ventures' sole limited partner is Battelle Memorial Institute (Battelle), the world's largest nonprofit independent research and development organization, with more than 20,000 employees in more than 120 locations worldwide, including at the National Laboratories that Battelle manages or co-manages for the U.S. Department of Energy:

- Brookhaven National Laboratory, Upton, New York

- Idaho National Laboratory, Idaho Falls, Idaho

- National Renewable Energy Laboratory, Golden, Colorado

- Oak Ridge National Laboratory, Oak Ridge, Tennessee

- Pacific Northwest National Laboratory, Richland, Washington

- Lawrence Livermore National Laboratory - Livermore, California

- Battelle also has contracts to manage the Department of Homeland Security's National Biodefense Analysis \& Countermeasures Center and the National Institute of Health's High Containment Integrated Research Facility. Both are scheduled to open in 2008 at Fort Detrick - Frederick, Maryland

For more information about Battelle, go to www.battelle.orq.

Source: http://www.battelleventures.com/more background.html, accessed May 4, 2009. 
Exhibit 8: Proposed Ampulse technology manufacturing benefits.

\section{c-Si PV Wafer Production: Costly \& Inefficient}

- 2 yr energy payback

- $\$ 0.60 / \mathrm{W}-\$ 1.00 / \mathrm{W}$ for feedstock alone

Sand

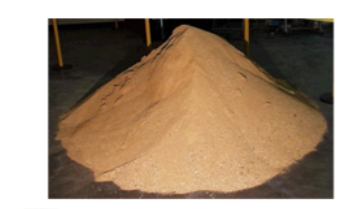

Add carbon and energy
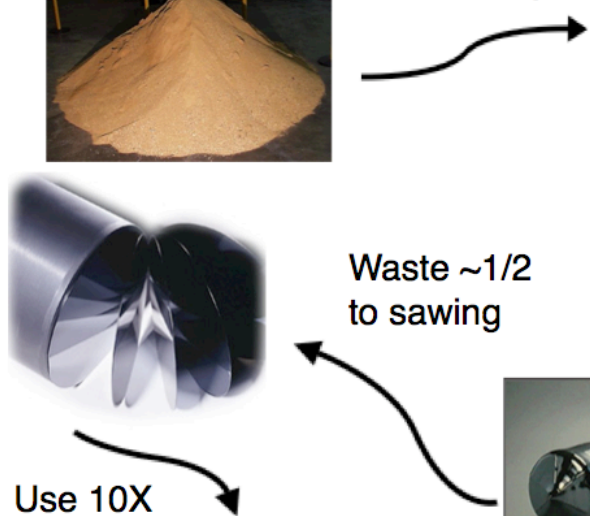

more than needed

to sawing

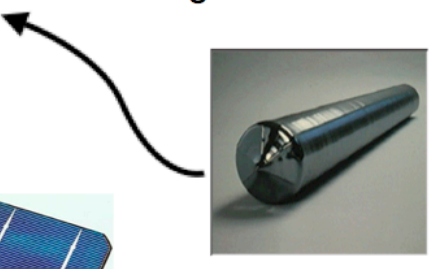

Purest material:

$\mathrm{SiHCl}_{3}$ or $\mathrm{SiH}_{4}$ gas
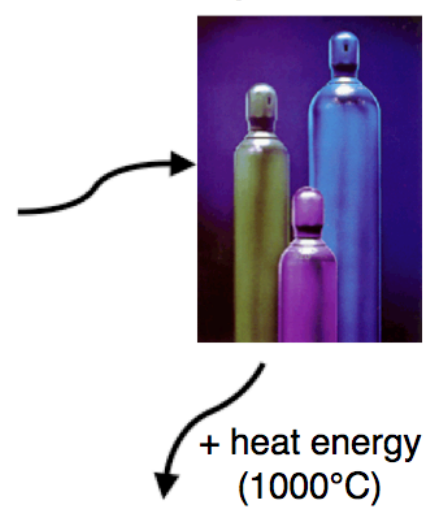

allurgical

grade $\mathrm{Si}$

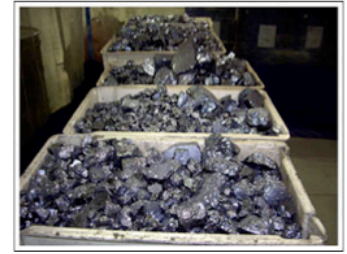

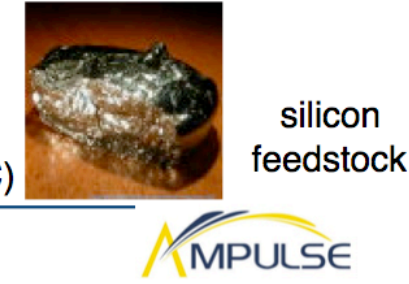

+ more heat energy $\left(1500^{\circ} \mathrm{C}\right)$

MPULSE

\section{Film-Si: Breakthrough Process Efficiency}

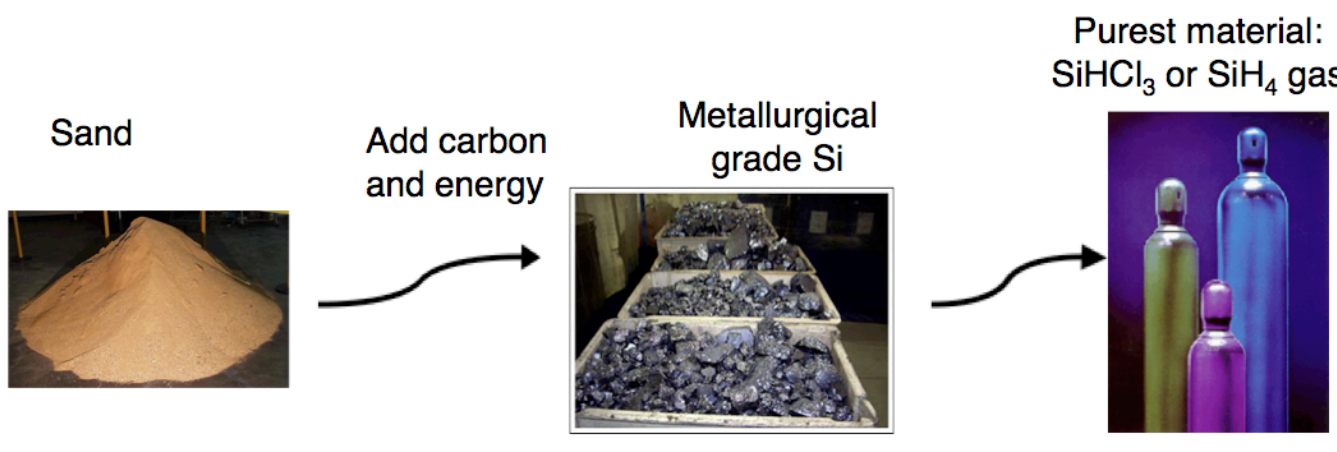

direct-film c-Si growth

- little waste

- 2/3rd less energy input

- no Si feedstock

- monolithic integration
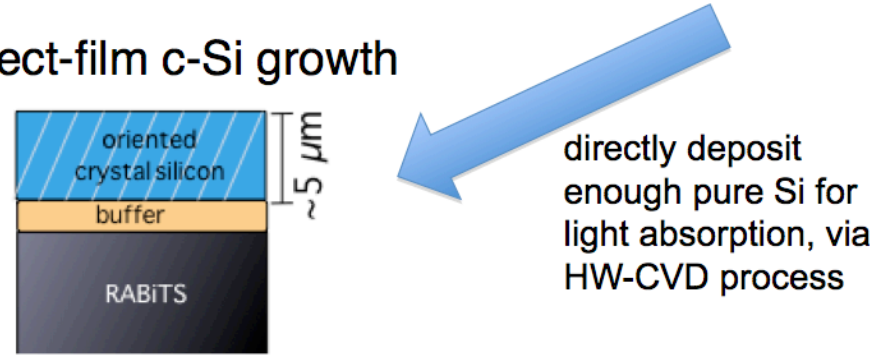
enough pure Si for light absorption, via HWD process 


\section{Exhibit 8 con't.}

\section{Ampulse Manufacturing Process Flow}

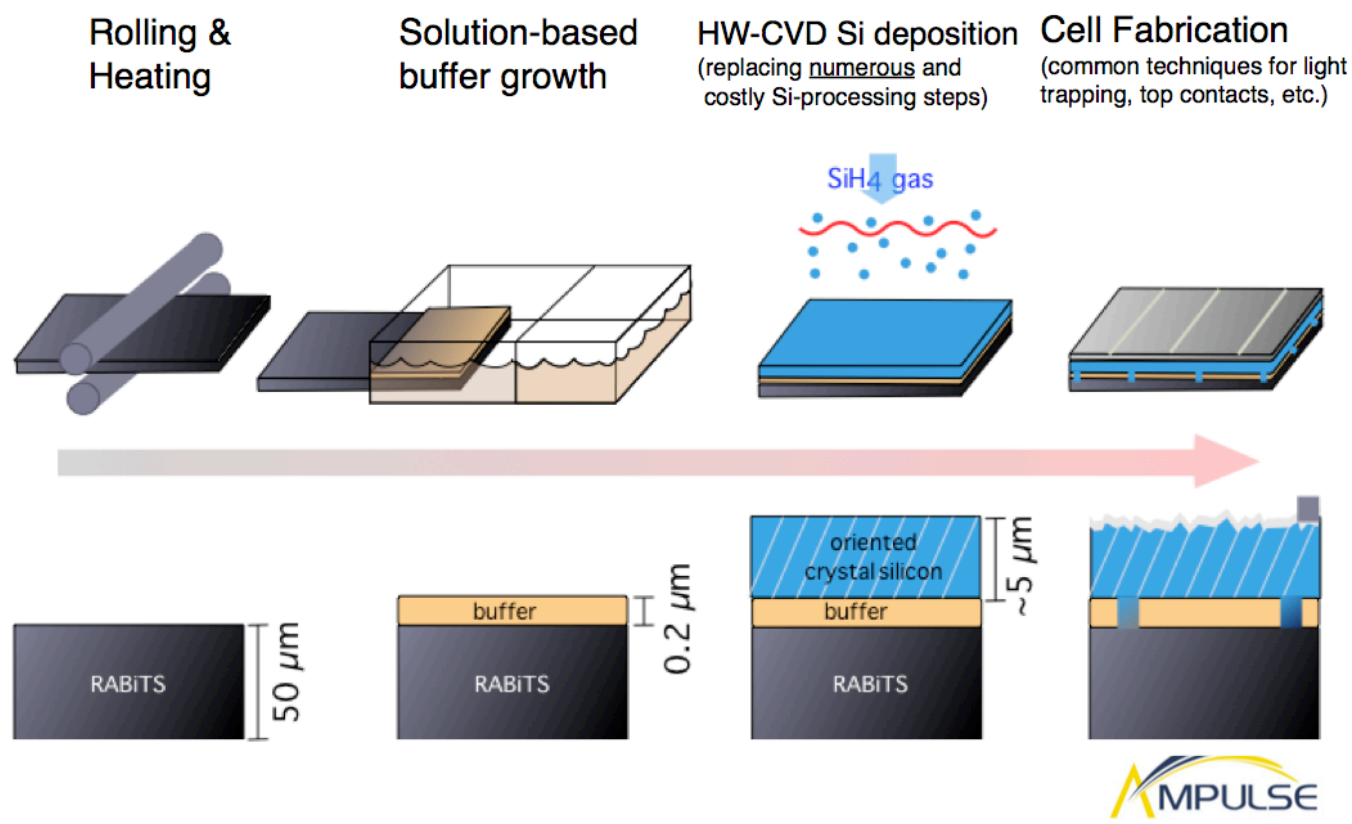

Source: Ampulse company documents, accessed Jan 19, 2010.

Exhibit 9: Description of TCDF funding for Ampulse.

Through the Department of Energy's (DOE) Technology Commercialization Development Fund (TCDF), NREL has received $\$ 4$ million this fiscal year to facilitate collaborative R\&D projects between researchers and companies to develop commercial products based on NREL innovations. Commercial partners share $50 \%$ or more of the project development costs, which will typically range from $\$ 150,000$ to $\$ 1$ million. Projects are selected based on their fit with the TCDF program, the value of NREL's intellectual property position, and the potential for near-term commercial impacts. Both NREL researchers and outside industry can submit project proposals to the NREL Technology Transfer Office. The TCDF program gives NREL some wonderful tools to address the commercialization "valley of death" between technologies in the laboratories and products in the private sector. We expect the program to increase the market impact of NREL's technologies. In addition, the program has shown the ability to support faster, more nimble partnering to make it happen. For our first TCDF project [with Ampulse], we moved from first contact with a startup company through executing a license option and initiating work on a cooperative project to commercializing the product in only 17 days. Moving at the "speed of business" is difficult at a national laboratory, but absolutely critical to us in meeting the opportunities and challenges presented in the market.

Source: http://www.nrel.gov/technologytransfer/investing clean energy.html, accessed May 4, 2009. 


\section{Exhibit 10: Ampulse biographies.}

\section{Steve Hane - President \& Chief Executive Officer}

Steve joins Ampulse with an outstanding performance record in leadership roles within both venturebacked start-ups and large-scale businesses. Prior to Ampulse, Hane was president and CEO of Picolight, Inc., a pioneer in designing and manufacturing the vertical cavity surface emitting laser (VCSEL), a key technology used in high-speed short-to-medium-distance optical interconnects. Within two years of assuming top positions at Picolight, he architected a company restart that produced dramatic increases in revenue, profitability and customer acceptance of Picolight's optical technologies. Steve orchestrated successful \$125-million sale of Picolight to JDSU in mid-2007.

From 2000 to 2004, Steve was vice president of business development for LightPointe Communications, a free-space optics manufacturer. He played a leadership role in strategic-partnership development with Cisco, Siemens, Corning and Huawei, and drove deployments of FSO with top service providers, including Qwest and Nextel. Previous to LightPointe, Steve was vice president in the Business Broadband Group of ADC responsible for North American sales. Steve was instrumental in leading ADC's network transport and access product group to a \$500-million revenue run-rate, with more than 70 product approvals in an eight-year span of service.

Steve holds a bachelor's degree in geological engineering from the University of Minnesota's Institute of Technology (1983). With his present efforts focused on emerging clean technologies, Steve serves on the advisory board of the University of Colorado's Deming Center for Entrepreneurship, was named the 2008 "National Clean Energy Entrepreneur of the Year" for early seed ventures at the 21st NREL Industry Growth Forum, and is a founder and member of the first Board of Directors for the launch of the Colorado Cleantech Industry Association (CCIA) in early 2009.

\section{Paul Schroeter - Chief Operating Officer}

Paul is a strong data-driven leader of R\&D, operations, and engineering with a record of success in organizations ranging from pre-product start-ups to $\$ 500$ million public companies. Previously as COO and Senior Vice President at Neophotonics Corp., a leading designer and manufacturer of optical components, modules, and subsystems, Paul was responsible for research and development, operations, and engineering, both domestic and international. He grew the company from a 25-person materials research startup to an industry leader with over 2,300 employees and revenue over $\$ 125$ million annually, recognized industry-wide for technical excellence, on-time delivery of complex integrated optical components, and outstanding customer service to customers.

As Vice President of Operations and Engineering at Read-Rite Corp, Paul was a primary contributor in transforming Read-Rite from a \$10 million per year, 250-employee company in a bankrupt position into the largest independent supplier of thin film computer disk heads employing 10,000 people with $\$ 500$ million in revenue. Earlier in his career, as an Engineering Manager at Advanced Micro Devices, Paul Started three separate high volume semi-conductor wafer fabrication/production facilities from initial planning and set up, through daily operations and transferred processes from R\&D into production. Paul received his B.S. in Electrical Engineering in 1977 at University of Illinois, Urbana.

\section{Scientific Team}

Ampulse core R\&D team has a strong backing from a number of distinguished scientists and inventors with several decades of combined photovoltaic experience from Oak Ridge and NREL. These scientists are involved with the development of Ampulse's technology on an ongoing basis.

Source: Ampulse company document, accessed June 30, 2009. 
Exhibit 11: Hane's perception of the clean tech opportunity space and the roles of transitioning executives.

\section{Cleantech - Opportunity Climate}

* There are a lot of good, but underdeveloped, ideas

- heavy technology emphasis, light assessment of business viability

- get ready to work on very early stage projects, and for the long-haul

- these businesses will be clashing up against established momentum

* Misconception: innovators = entrepreneurs

- the very things that make innovators great often work against them as entrepreneurs

- the multi-tasking "art" of entrepreneurship is widely undervalued

\section{Misconception: VC money + innovation = company}

- technology is $20 \%$ of the picture, same for funding

- team, market insertion strategy, and a practical business/operations model are equally critical; team most critical of all

- one of those factors out of whack = game over

\section{Your Value as a "Cross-over" Executive}

\section{professional management experience}

- real businesses, real P\&L responsibilities teach grounding lessons

- these businesses will need people who have "seen it before"

\section{objectivity and perspective}

- you have to be able to represent business practice on equal footing with the technical proposition

- someone has to judge between "relevance" and "fascination"

\section{risk management vs. risk-taking}

- VCs don't take risks - they work to manage the risks of nascency

- VCs don't invest in R\&D - they want "D" after a proving-level of "R"

- VCs want "adult supervision", candor, and judgment applied to interesting propositions - and "we were wrong" may be the answer

Your core value in crossing-over is not domain expertise in technology 
Exhibit 12: Ampulse timeline when Hane joined as CEO.

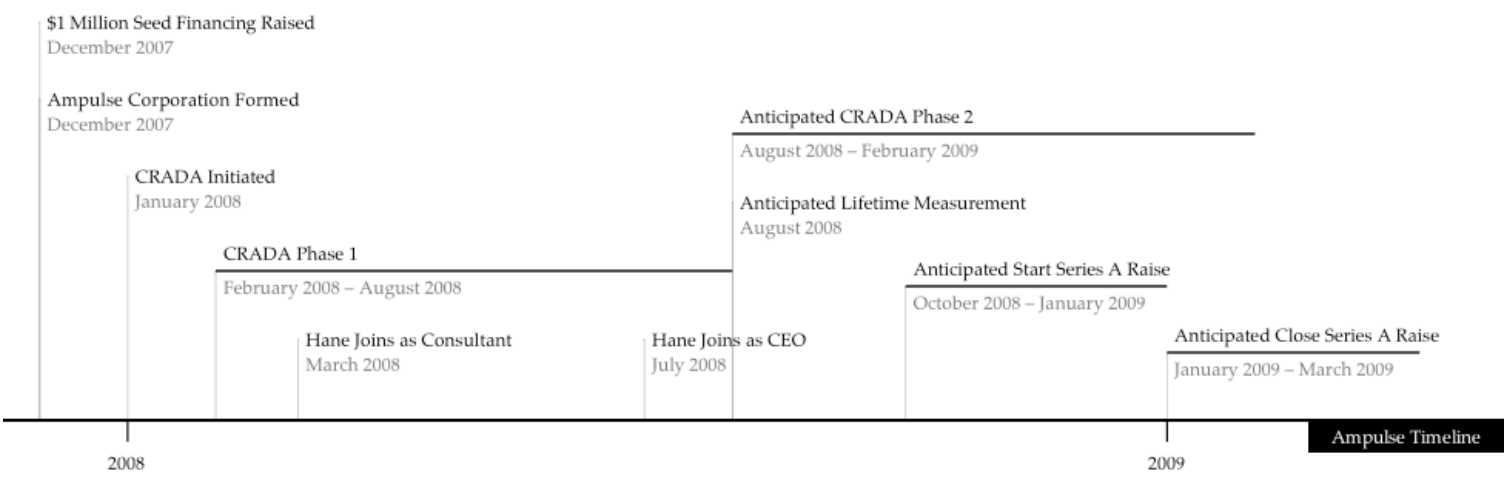

Source: Casewriter.

Exhibit 13: Example of what a virtual company CEO does; one page of many from Hane's Ampulse task list, including the "department" designated to do the work.

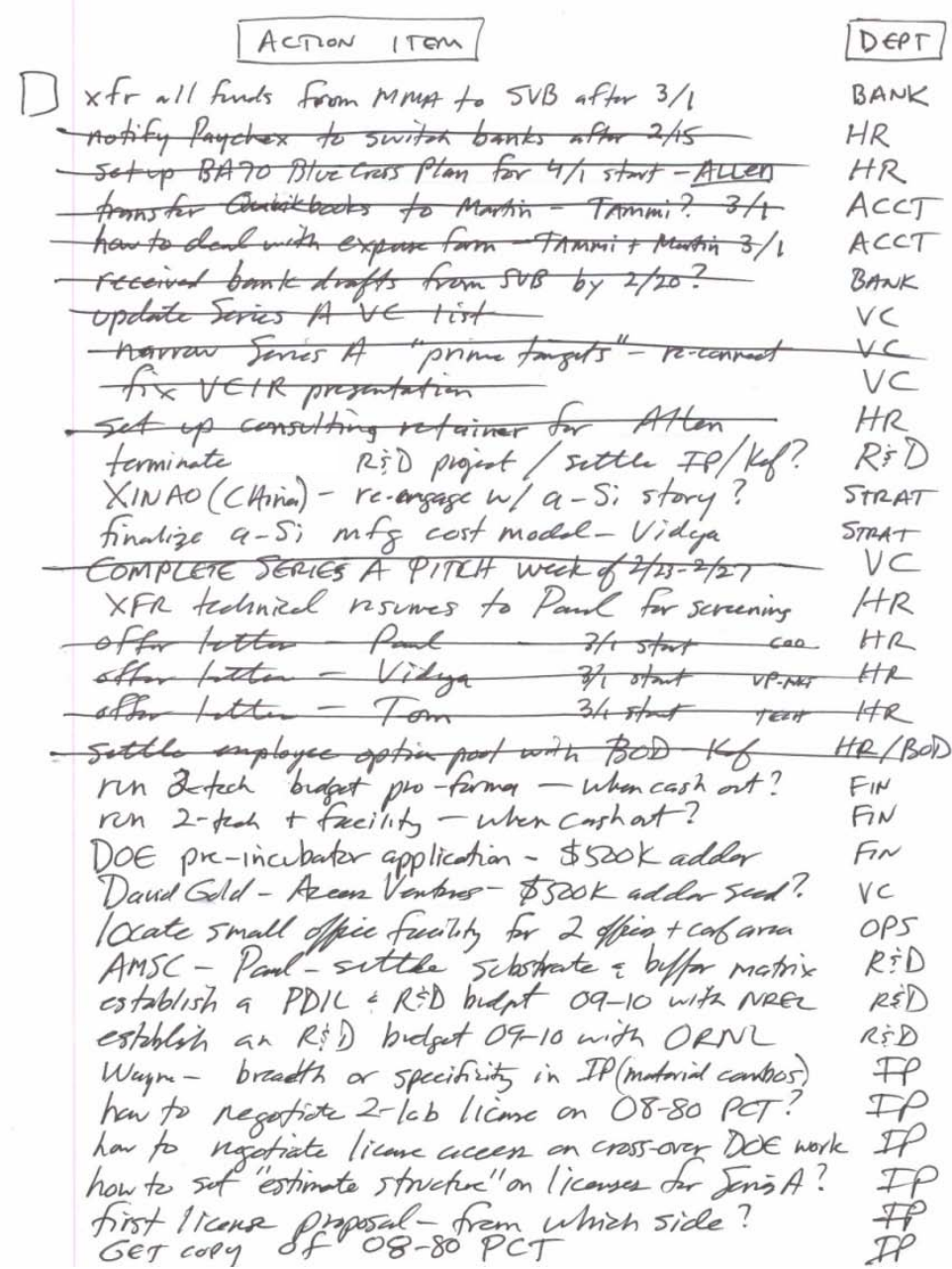

Source: S. Hane, May 5, 2009. 
Exhibit 14: Record test solar cell efficiencies across several photovoltaic areas.

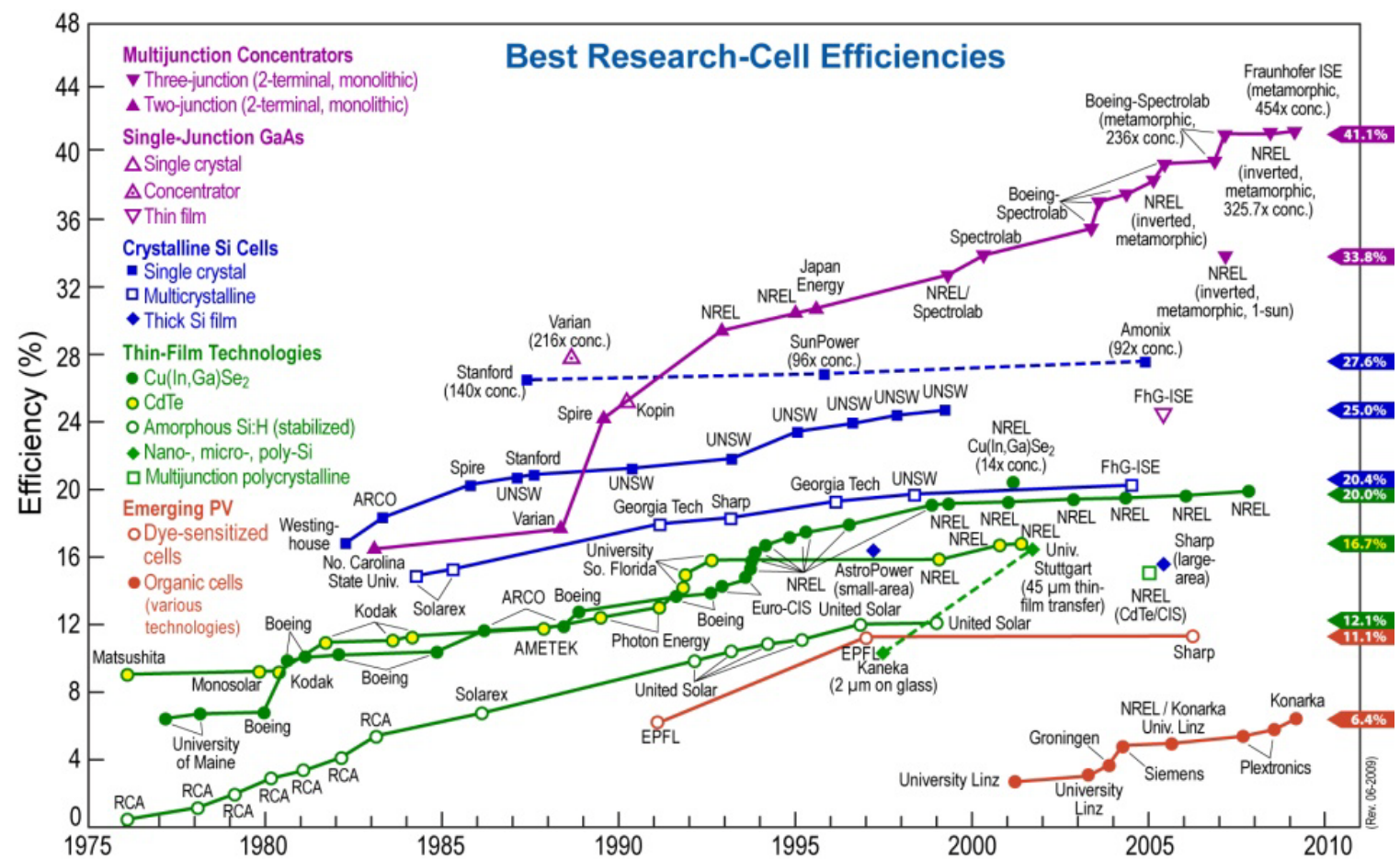

Source: NREL.

Exhibit 15: NREL's photovoltaic knowledge dissemination through publication and patenting.

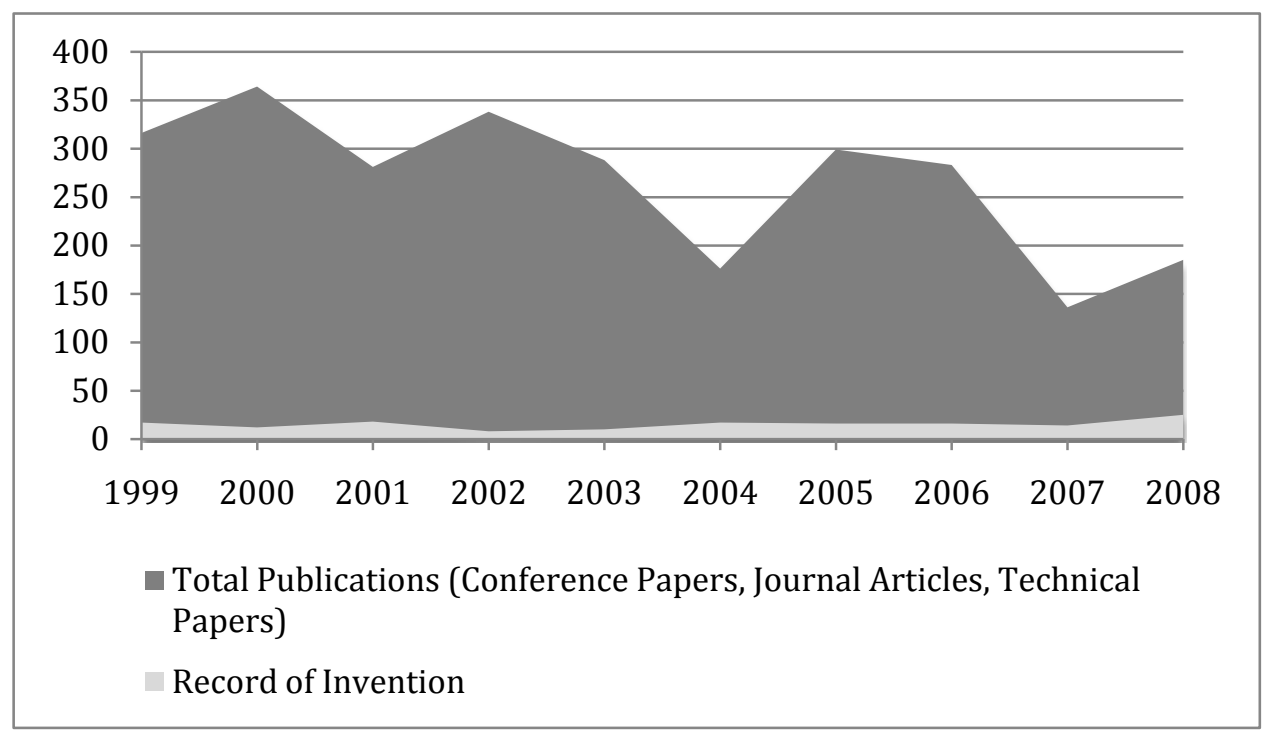

Source: NREL. 
Exhibit 16: Teplin's personal web site.

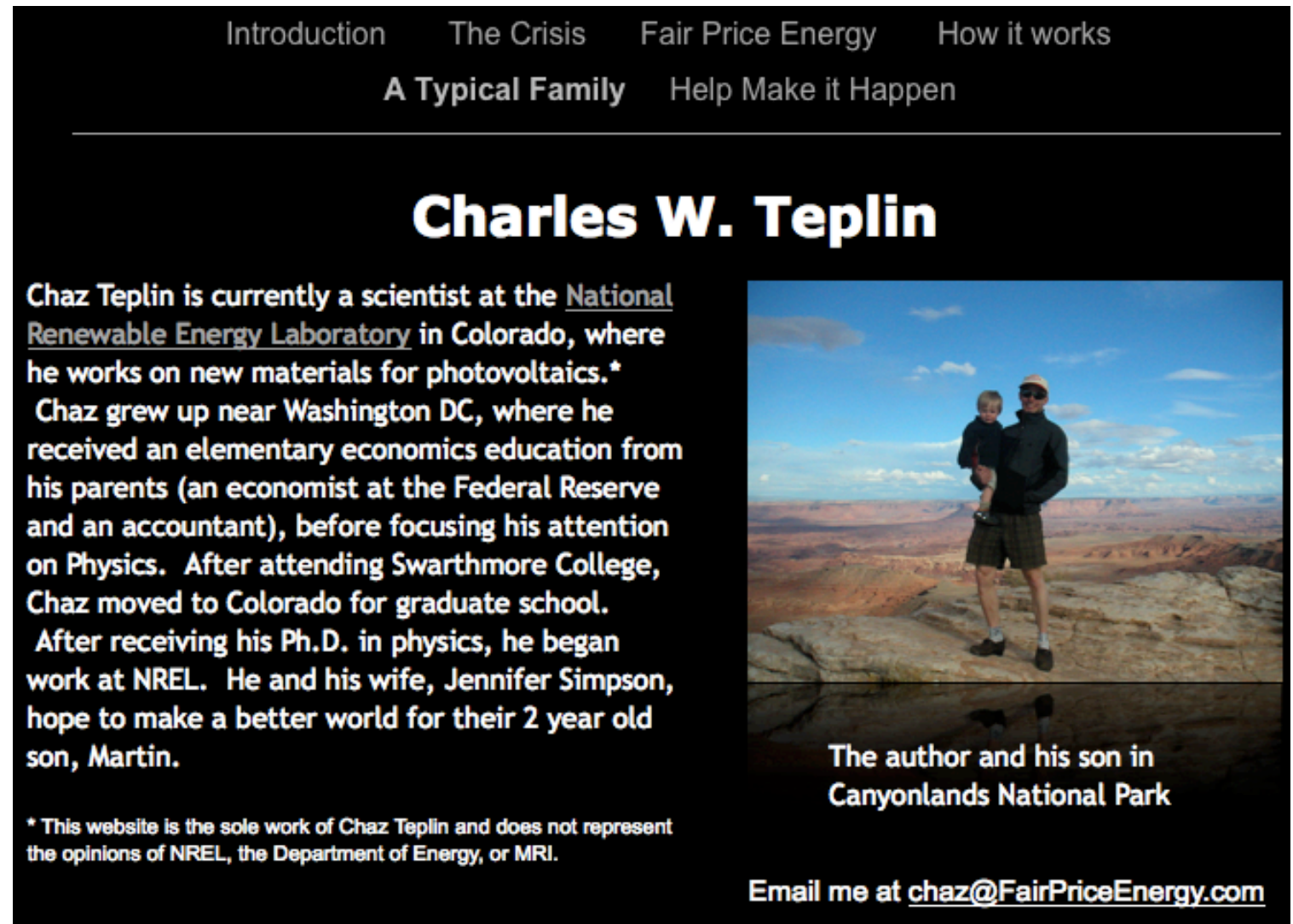

Source: http://fairpriceenergy.com/FairPriceEnergy/About\%20the\%20Author.html, accessed May 8, 2009. 


\section{REPORT DOCUMENTATION PAGE}

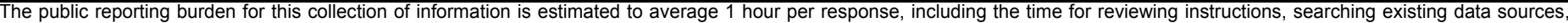

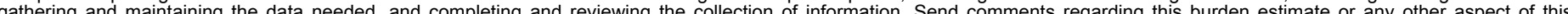
(0704-0188). Respondents

should be aware that notwithstanding any other provision of law, no person shall be subject to any penalty for

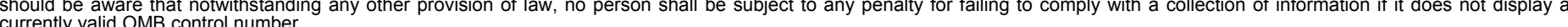

PLEASE DO NOT RETURN YOUR FORM TO THE ABOVE ORGANIZATION.

\begin{tabular}{l|l|l|l} 
1. REPORT DATE (DD-MM-YYYY) & 2. REPORT TYPE & 3. DATES COVERED (FrOm - TO)
\end{tabular}

March 2010

Technical Report

4. TITLE AND SUBTITLE

Ampulse Corporation: A Case Study on Technology Transfer in U.S.

Department of Energy Laboratories 5a. CONTRACT NUMBER

DE-AC36-08-GO28308

5b. GRANT NUMBER

5c. PROGRAM ELEMENT NUMBER

5d. PROJECT NUMBER

NREL/TP-7A1-46860

5e. TASK NUMBER

7A10.1000

5f. WORK UNIT NUMBER
7. PERFORMING ORGANIZATION NAME(S) AND ADDRESS(ES)

National Renewable Energy Laboratory

1617 Cole Blvd.

Golden, CO 80401-3393
8. PERFORMING ORGANIZATION REPORT NUMBER

NREL/TP-7A1-46860

9. SPONSORING/MONITORING AGENCY NAME(S) AND ADDRESS(ES)

10. SPONSOR/MONITOR'S ACRONYM(S) NREL

11. SPONSORING/MONITORING AGENCY REPORT NUMBER

12. DISTRIBUTION AVAILABILITY STATEMENT

National Technical Information Service

U.S. Department of Commerce

5285 Port Royal Road

Springfield, VA 22161

13. SUPPLEMENTARY NOTES

14. ABSTRACT (Maximum 200 Words)

An overview of NREL's partnership with Ampulse, a startup company, providing insight about how industry can successfully work with a U.S. Department of Energy lab.

\section{SUBJECT TERMS}

Ampulse; CRADAs; cooperative research and development agreements; startup companies; technology commercialization and deployment fund; TCDF

\begin{tabular}{|c|c|c|}
\hline $\begin{array}{l}\text { a. REPORT } \\
\text { Unclassified }\end{array}$ & $\begin{array}{l}\text { b. ABSTRACT } \\
\text { Unclassified }\end{array}$ & $\begin{array}{l}\text { c. THIS PAGE } \\
\text { Unclassified }\end{array}$ \\
\hline
\end{tabular}

\begin{tabular}{l|l} 
17. LIMITATION & 18. \\
OF ABSTRACT & OF PAGES \\
UL &
\end{tabular}

19a. NAME OF RESPONSIBLE PERSON

19b. TELEPHONE NUMBER (Include area code) 